\title{
An Analysis of Klobučarić's Depictions of the Kvarner Littoral
}

\author{
Ivka KLJAJIĆ1 and Miljenko LAPAINE2* \\ University of Zagreb, Faculty of Geodesy, Kačićeva 26, 10000 Zagreb, Croatia \\ 1ikljajic@geof.hr, 2mlapaine@geof.hr
}

\begin{abstract}
*Since the second author is the journal's managing editor, the peer review process and independent editorial decision were performed by an external editor, Dr. Dubravka Mlinarić.

We thank Dr. Dubravka Mlinarić for her help in addressing potential managing editor's conflict of interest.
\end{abstract}

\begin{abstract}
Ivan Klobučaric was one of the most important Croatian cartographers at the turn of the 17th century. In 1579 he produced a panorama of Rijeka which is kept in the War Archives (Kriegsarchiv) in Vienna. The Styrian Provincial Archives (Steiermärkische Landesarchiv) in Graz houses a map of the Bay of Rijeka with a panorama of the city dated 1586, attributed to Klobučarić. His cartographic legacy created between 1601 and 1605 can be found in the Clobucciarich - Skizzen collection. It comprises 108 sheets. Most are double-sided. Some pages show two or more items, so that the entire collection includes around 500 cartographic depictions. In terms of western Croatia, there are about twenty. This paper provides a list of the contents of Klobučarićs cartographic depictions relating to the area of Croatia. A sketch of the Kvarner Littoral from Rijeka to Sveti Juraj with the mainland hinterland is described, with a map of parts of Croatia from Rijeka to Omiš with the mainland hinterland. An analysis was conducted of the contents of the parts of the sketch and map showing the Kvarner Littoral, comparing the representation of settlements showed and those omitted, with toponyms on the map and those shown on earlier maps of the Kvarner Littoral. The paper indicates errors in previous works about Klobučarić's life, work and cartographic activities.
\end{abstract}

Keywords: Ivan Klobučarić, Croatia, Kvarner Littoral, cartography, toponym

\section{Introduction}

Little has been written about Ivan Klobučarić, priest, artist and cartographer, in Croatian and foreign publications to date, and his extensive cartographic activities have not been thoroughly researched or described. He was born between 1545 and 1550 in Dubašnica on the island of Krk. He died towards the end of 1605 or possibly early in 1606 in Fürstenfeld, or perhaps in Rijeka. In the literature he is known as Giovanni, Hans, Ionnes, Joannes, or Johannes, and versions of his surname include Clobuciarich, Clobucciarich, Clobucarius, Clobucciarius, Klobučijarič, Klobucziarich, with the monikers de Flumine, Fiumano, Fluminensis, or Riječan.

Klobučarić was an Augustinian monk who entered the Augustinian monastery in Rijeka around 1560. He

46 was educated there and ordained in 1572. From 1572 to 1575 he resided at Santo Stefano Rotonda Monastery in Rome. It was probably in Rome that he honed his artistic skills. In the Register of the General Prior of the Augustinian Order kept in the Archives of the Augustinian Order in Rome, on a sheet dated 5 June 1575, there is an entry which reads (in translation), “... Brother Ivan of Rijeka is permitted to return to his homeland to pursue painting ...". This entry indicates that he was perceived as an artist at the time when he left Rome for Rijeka (Klen 1974, 1975; Peloza 1975).

On his return to Rijeka in 1575 he was appointed vicar general of the Augustinian monastery. He was prior of the Rijeka monastery from 1577 to 1580,1588 to 1590 , in 1592, and in 1597. It also appears from the monastery records that he was the prior in 1585 and 1587. At

KiG No. 30, Vol. 17, 2018, https://doi.org/10.32909/kg.17.30.4 - - 


\title{
Analiza sadržaja Klobučarićevih prikaza Kvarnerskog primorja
}

\author{
Ivka KLJAJIĆ1 i Miljenko LAPAINE2* \\ Sveučilište u Zagrebu, Geodetski fakultet, Kačićeva 26, 10000 Zagreb, Hrvatska \\ 1ikljajic@geof.hr, 2mlapaine@geof.hr

\begin{abstract}
${ }^{*}$ S obzirom na to da je drugi autor izvršni urednik ovoga časopisa, recenziranje je obavila i neovisnu uredničku odluku donijela vanjska urednica dr. sc. Dubravka Mlinarić.
\end{abstract} \\ Zahvaljujemo dr. sc. Dubravki Mlinarić na pomoći vezanoj uz potencijalni sukob interesa izvršnog urednika.
}

\begin{abstract}
Sažetak. Ivan Klobučarić jedan je od najznačajnijih hrvatskih kartografa s kraja 16. i početka 17. stoljeća. Autor je panoramske vedute Rijeke iz 1579. koja se čuva u Ratnom arhivu (Kriegsarchiv) u Beču. U Štajerskom zemaljskom arhivu (Steiermärkische Landesarchiv) u Grazu nalazi se karta Riječkog zaljeva s vedutom Rijeke iz 1586. koja se pripisuje Klobučariću. U tom Arhivu, u fondu Clobucciarich - Skizzen čuva se Klobučarićeva kartografska ostavština nastala u razdoblju 1601-1605. Sastoji se od 108 listova. Na većini listova prikazi se nalaze s obiju strana papira. Na pojedinim stranicama postoje dva ili više prikaza, tako da čitav fond sadrži oko 500 kartografskih prikaza. Za područje zapadne Hrvatske, Klobučarićeva ostavština sadrži dvadesetak kartografskih prikaza. U radu je dan popis sadržaja Klobučarićevih kartografskih prikaza koji se odnose na područja Hrvatske. Opisana je skica Kvarnerskog primorja od Rijeke do Sv. Jurja s kopnenim zaleđem i karta dijela Hrvatske od Rijeke do Omiša s kopnenim zaleđem. Provedena je analiza sadržaja dijela skice i karte na kojem je prikazano Kvarnersko primorje, usporedbom zastupljenosti naselja koja je Klobučarić prikazao i onih koja nije te usporedbom toponima sadržanih na karti s toponimima prikazanim na ranije izrađenim kartama na kojima je prikazano Kvarnersko primorje. Ukazano je na pogreške uočene u dosadašnjim radovima o Klobučarićevu životu i njegovu kartografskom djelovanju.
\end{abstract}

Ključne riječi: Ivan Klobučarić, Hrvatska, Kvarnersko primorje, kartografija, toponim

\section{Uvod}

O Ivanu Klobučariću, svećeniku, slikaru i kartografu pisano je $u$ hrvatskim i inozemnim publikacijama, ali njegovo bogato kartografsko djelovanje još uvijek nije dovoljno istraženo i opisano. Klobučarić se rodio oko 1545. ili oko 1550. u Dubašnici na otoku Krku. Umro je u drugoj polovici 1605. ili u prvoj polovici 1606. u Fürstenfeldu ili u Rijeci. U literaturi je zabilježen i kao Giovanni, Hans, Ioannes, Joannes, Johannes, s prezimenskim inačicama Clobuciarich, Clobucciarich, Clobucarius, Clobucciarius, Klobučijarič, Klobucziarich te s dodatkom de Flumine, Fiumano, Fluminensis, Riječan.

Klobučarić je augustinskom redu pristupio $u$ augustinskom samostanu u Rijeci oko 1560. Ondje se školovao i 1572. bio zaređen za svećenika. Od 1572. do 1575. proveo je $u$ samostanu Santo Stefano Rotondo $u$ Rimu. Vjerojatno je u Rimu izučio slikarske vještine. U Registru generalnih priora augustinskog reda koji se čuva u Arhivu augustinskog reda u Rimu, na jednom listu koji je datiran 5. lipnja 1575. nalazi se zapis koji u prijevodu glasi: ,....bratu Ivanu Riječanu daje se dozvola da se vrati u domovinu i da se bavi slikarstvom...". Taj zapis ukazuje da je Klobučarić u trenutku kad odlazi iz Rima u Rijeku slikar (Klen 1974, 1975; Peloza 1975).

Po povratku u Rijeku 1575. imenovan je generalnim vikarom augustinskog samostana. Prior riječkog augustinskoga samostana bio je 1577-1580., 1588-1590., 1592., 1597. Iz spisa samostana proizilazi da je prior bio i 1585 . i 1587. Tih je godina bio i prior samostana u Fürstenfeldu (Klen 1974, 1975). 
that time, he was also the prior of the Fürstenfeld monastery (Klen 1974, 1975).

In 1578, he was sent by the Archduke Charles II on a confidential mission to Pope Gregory XIII in Rome, accompanied by Captain Gašpar Raab. Thanks to Klobučarić's efforts, the Augustinian monastery in Graz was founded in 1580 . As a result of certain envious attitudes and accusations, he was summoned before the Prior General of the order in 1579, 1582, and 1594, and appeared before the Holy Inquisition in 1595 (Klen 1974; Peloza 1975).

Klobučarić was prior in 1584 and vicar in 1592 at the monastery in Völkermarkt. He was prior in Fürstenfeld in 1585,1587 , from the beginning of 1593 to the autumn of 1594, from February 1600, with one interruption in 1602 , and until the end of 1603 . He was provincial several times, and in 1584 and 1592 vicar of the StyrianCarinthian Augustinian province. In 1592 he held three posts simultaneously; prior in Rijeka, vicar of the Styrian-Carinthian province, and vicar general of the monastery in Völkermarkt (appointed in the May of that year) (Laszowski 1937; Klen 1974, 1975; Žic 2003). Laszowski (1937) also mentions that he was prior of Fürstenfeld monastery in 1596 and 1598.

Klobučarić painted and drew landscapes, topographic sketches and panoramic views (Lapaine and Kljajić 2009), so we are pleased to present this contribution to a study of his cartographic work, particularly his depictions of the Kvarner Littoral.

\section{Klobučarić’s Cartographic Work}

The panorama of Rijeka and the surrounding area (1579) is considered one of Klobučarić's best known works. It is housed in the War Archives (Kriegsarchiv) in Vienna under call no. G-1-h-171. It has no title and is unsigned. It is the first known depiction of Rijeka, the city fortifications (as they were then), streets and buildings (Klen 1974, 1975; Marković 1993, 2001, 2001). ${ }^{1}$ We established that several Croatian researchers (Marković 1993, 2001, 2002; Slukan Altić 2003; Nepokoj 2010) published only excerpts of the panorama without mentioning that it is an excerpt. We noted that the excerpts had been edited, and that colours and frames not found in the original had been added. Based on these additions, readers might be tempted to conclude that there were several versions of the panorama.

Klobučarić has been attributed as the author of the 1586 map of the Bay of Rijeka. The map has no title or signature. It is housed in the Styrian Provincial Archives

${ }^{1}$ A reproduction of the panorama was published in the work (Klen 1974).
(Steiermärkische Landesarchiv) in Graz. It was drawn in black ink which has faded to brown. Later, the sea was coloured blue and the land green, using watercolours (Klen 1974, 1975; Marković 1993, 2002).2

Armed with a warrant from Archduke Ferdinand II, Klobučarić travelled around parts of modern Austria, Slovenia and Croatia between 1601 and 1605, collecting topographic material for his map. The cartographic legacy produced in the following years is kept in the Styrian Provincial Archives in Graz in the Clobucciarich - Skizzen collection. It comprises 108 sheets in four groups: 16 sheets measuring $32 \times 21.5 \mathrm{~cm}, 80$ sheets measuring $43 \times 32$ $\mathrm{cm}$ (one is missing), four folio sheets and eight written documents. The documents include patents, or authorisations for Klobučarić's cartographic work. Most have cartographic depictions on both sides. Some pages show two or more items, so that the entire collection comprises over 500 cartographic depictions. The sheets are numbered according to the paper size. They show most of Styria, Carniola, Gorizia, Croatia, Austrian Istria and part of Carinthia. Most of the cartographic depictions cover modern-day Austria. Slovenia is also well represented. Croatia appears on twenty depictions. They are of different sizes and grades, from rough sketches to detailed, finished drawings, topographic sketches, panoramas of settlements, fortified towns and castles, fortresses, city walls and ground plans, most of which include many toponyms and several notes. Klobučarić used pencil, charcoal and a quill pen to produce the depictions. His favourite method was pencil. He additionally emphasised some buildings and toponyms in black ink and sepia (Popelka 1923, 1932; Klen 1974, 1975; Marković 2002).

Klobučarić began his cartographic work in the service of Ferdinand II in May 1601, when he was given the task of producing a map of Styria. He first travelled to Styria between 24 May and 13 June 1601. This can be seen in a note he wrote on sheet 103 of his legacy, attaching the expense account for his travels during that period. On 8 July 1601, abbot Admont issued Klobučarić with a patent ordering all stewards, officials and subjects of the abbey estates to offer him protection, assistance and advice, since he held a commission to inspect, describe and depict the towns, cities, borders and boundaries of Styria, including Admont monastery. The patent can be found on sheets 101 and 102 of Klobučarićs legacy. Between 1601 and 1603, Klobučarić worked mostly in Styria, Carinthia and Carniola (Popelka 1923, 1932; Klen 1974, 1975; Marković 2002). ${ }^{3}$ We noted that some researchers

\footnotetext{
${ }^{2}$ A reproduction of the map was published in the works (Klen 1975; Marković 2002).

${ }^{3} \mathrm{~A}$ translation of the patent in Croatian is provided by Marković (2002).
}

KiG No. 30, Vol. 17, 2018, https://doi.org/10.32909/kg.17.30.4 - - 
Godine 1578. poslao ga je nadvojvoda Karlo II. u povjerljivu misiju papi Grguru XIII. u Rim, zajedno s kapetanom Gašparom Raabom. Klobučarićevom zaslugom je 1580. utemeljen augustinski samostan $u$ Grazu. Zbog nekih zavisti i optužbi bio je pozvan pred generalnog priora reda 1579., 1582. i 1594., a pred Svetu inkviziciju 1595. godine (Klen 1974; Peloza 1975).

Klobučarić je bio prior 1584. i vikar 1592. samostana u Völkermarktu. Prior augustinskog samostana u Fürstenfeldu bio je 1585., 1587., od početka 1593. do jeseni 1594., od veljače 1600., uz jedan prekid u 1602. godini, do kraja 1603. Više je puta bio provincijal te 1584. i 1592. vikar štajersko-koruške augustinske provincije. Godine 1592. istovremeno je bio na tri dužnosti reda: prior u Rijeci i vikar štajersko-koruške provincije, a u svibnju iste godine imenovan je i za generalnog vikara samostana u Völkermarktu (Laszowski 1937; Klen 1974, 1975; Žic 2003). Osim navedenih godina, Laszowski (1937) piše da je Klobučarić bio prior samostana u Fürstenfeldu i 1596.i 1598.

S obzirom na to da se Klobučarić bavio slikanjem i crtanjem krajolika, izradom topografskih skica i panoramskih veduta (Lapaine i Kljajić 2009), stoga u radu donosimo prilog proučavanju njegova kartografskog djelovanja, posebno njegovih kartografskih prikaza Kvarnerskog primorja.

\section{Klobučarićevo kartografsko djelovanje}

Među najpoznatijim Klobučarićevim kartografskim radovima smatra se panoramska veduta Rijeke s okolicom iz 1579. Čuva se u Ratnom arhivu (Kriegsarchiv) u Beču pod signaturom G-1-h-171. Veduta je bez naslova i bez imena autora. To je prvi poznati prikaz Rijeke, izgled tadašnjih gradskih utvrda, ulica i građevina (Klen 1974, 1975; Marković 1993, 2001, 2002)1. . Utvrdili smo da su pojedini hrvatski istraživači u svojim radovima (Marković 1993, 2001, 2002; Slukan Altić 2003; Nepokoj 2010) objavili samo isječak vedute ne navodeći da je to isječak. Uočili smo da su ti iscječci vedute uređivani, dodatno su bojani, dodavani su im okviri kojih nema u izvorniku. $\mathrm{Na}$ temelju toga, čitatelji bi mogli zaključiti da postoji više primjeraka te vedute.

Autorstvo karte Riječkoga zaljeva s vedutom Rijeke iz 1586. pripisuje se Klobučariću. Karta je bez naslova i imena autora. Čuva u Štajerskom zemaljskom arhivu (Steiermärkische Landesarchiv) u Grazu. Izrađena je crnilom, koje je uslijed blijeđenja postalo smeđe. Naknadno je obojana akvarelnim bojama, more plavom bojom, a kopno zelenom (Klen 1974, 1975; Marković 1993, 2002)2.

\footnotetext{
${ }^{1}$ Reprodukcija vedute objavljena je u radu (Klen 1974).

2 Reprodukcija karte objavljena je u radovima (Klen 1975; Marković 2002).
}

ᄂ KiG Br. 30, Vol. 17, 2018, https://doi.org/10.32909/kg.17.30.4
Prema nalogu nadvojvode Ferdinanda II., Klobučarić je u razdoblju 1601-1605. obišao dijelove današnje Austrije, Slovenije i Hrvatske prikupljajući topografsko gradivo za izradu karte. Kartografska ostavština nastala u navedenom razdoblju čuva se u Štajerskom zemaljskom arhivu u Grazu, u fondu Clobucciarich - Skizzen. Sastoji se od 108 listova. Podijeljena je u četiri skupine: 16 listovaje formata $32 \times 21,5 \mathrm{~cm}, 80$ listova (jedan list nedostaje) dimenzija $43 \times 32 \mathrm{~cm}$, četiri lista folioformata i osam pisanih dokumenata. Među pisanim dokumentima su patenti, tj. ovlaštenja za Klobučarićev kartografski rad. Na većini listova s obiju stranica nalaze se kartografski prikazi. Na pojedinim stranicama postoje dva ili više prikaza, tako da čitav fond sadrži oko 500 kartografskih prikaza. Listovi su obilježeni rednim brojevima prema formatima papira. $\mathrm{Na}$ njima je prikazan veći dio tadašnje Štajerske, Kranjske, Gorice, Hrvatske, austrijske Istre i manji dio Koruške. Najveći broj kartografskih prikaza obuhvaća područja današnje Austrije. Dobro je zastupljeno i područje Slovenije. Hrvatska je zastupljena s dvadesetak kartografskih prikaza. Kartografski prikazi su različitih veličina i različitih stupnjeva dorađenosti, od grubih skica do dovršenih detaljnih crteža, topografskih skica, veduta naselja, burgova i dvoraca, utvrda, gradina i tlocrta nekih objekata, većinom s brojnim toponimima i nekim bilješkama. Za izradu prikaza Klobučarić se služio olovkom, ugljenom i perom. Veći dio prikaza izradio je olovkom. Na nekim prikazima, pojedine objekte i toponime naknadno je pojačavao perom i crnilom (sepijom) (Popelka 1923, 1932; Klen 1974, 1975; Marković 2002).

Kartografski rad u službi nadvojvode Ferdinanda II., Klobučarić započinje u svibnju 1601. kada je dobio zadatak da izradi kartu Štajerske. Prvo putovanje po Štajerskoj izveo je 24. svibnja do 13. lipnja 1601. To pokazuju Klobučarićeve zabilješke na 103. listu njegove ostavštine na kojem je pribilježio obračun troškova puta za navedeno razdoblje. Dana 8. srpnja 1601. opat Admonta izdao je Klobučariću patent kojim naređuje svim upraviteljima, službenicima i podanicima na admontskim imanjima da štite Klobučarića, pomognu mu, savjetuju ga jer on ima nalog da pregleda, opiše i izradi prikaze gradova, granica i međa Štajerske, a u njoj i samostana Admonta. Patent se nalazi na listovima 101-102 Klobučarićeve ostavštine. U razdoblju 1601-1603. Klobučarić je radio pretežito na području Štajerske, Koruške i Kranjske (Popelka 1923, 1932; Klen 1974, 1975; Marković 2002)3. Uočili smo da pojedini hrvatski istraživači (Marković 1993; Mlinarić 1998; Slukan Altić 2003) ne spominju Klobučarićevo kartografsko djelovanje u službi nadvojvode Ferdinanda II. za navedeno razdoblje.

${ }^{3}$ Prijevod patenta na hrvatski jezik donosi Marković (2002). 
(Marković 1993; Mlinarić 1998; Slukan Alić 2003) did not mention his cartographic work for Ferdinand II in this period.

Ferdinand II issued a patent on 6 September 1603 authorising Klobučarić to continue his cartographic work and extending it to include Inner Austria. The patent is kept in Klobučarić's legacy (sheets 104a and 104b). The Archduke ordered all subject authorities to collaborate with Klobučarić at all times. It appears from the patent that Klobučarić volunteered for this task (Marković 2002). ${ }^{4}$ In 1604 and 1605, he concentrated on Carniola and Austrian Istria (Popelka 1923; Klen 1974, 1975).

The last traces of Klobučarić's work include notes and sketches in response to a letter from Martio Marchesetti dated 26 August 1605. It is preserved in the legacy on sheets 107a and 107b. A chapter meeting of the Styrian-Carinthian Augustinian province was held on 27 April 1606. It included a list of all the monks in all six monasteries and there is no Klobučarić among them. Klobučarić died between two dates mentioned..$^{5}$ After his death, his estate (including his cartographic legacy) passed to the Augustinian monastery in Rijeka. According to a contract dated 3 May 1606, the monastery made his brother Juraj the lifelong beneficiary of his estate. In the summer of the same year, Juraj handed over the cartographic legacy to the Government of Inner Austria (Innerösterreichische Regierung) and requested compensation for his brother's services. In February 1607, the Court Chamber (Hofkammer) in Graz ordered 50 silver thalers to be paid to Petar Karal, to be delivered to Klobučarić's brother as per his request the previous summer (Popelka 1923, 1932; Laszowski 1937; Peruško 1958a; 1958b; Klen 1974, 1975; Marković 2002).

\subsection{Klobučarič's cartographic legacy}

The website of the Styrian Provincial Archives in Graz gives information on the history of the Clobucciarich Skizzen collection and how it came into existence. Andreas von Meiller of the Household-, Court- and State Archives (Haus-, Hof-, und Staatsarhiv) in Vienna researched the collections of documents in the Graz Burg between 28 August and 2 October 1846 . He extracted those he thought particularly important to be sent to Vienna, including Klobučarić's cartographic depictions. The selected documents arrived at the Archives at the end of 1847. Klobučarić's cartographic depictions were returned to Graz in 1922 with 49 other volumes (files) and became part

\footnotetext{
${ }^{4} \mathrm{~A}$ translation of the patent in Croatian is provided by Marković (2002).

${ }^{5}$ According to Marković, Klobučarić died in the spring of 1605 , but this is erroneous.
}

of the Meillerakten collection. Klobučarićs cartographic depictions were singled out for storage purposes and became a separate collection, Clobucciarich - Skizzen (URL 1). Popelka (1923) says that the call number for Klobučarić's legacy is Meillerakten, Fasz. 25a, while Peruško (1958a, 1958b) wrongly gives the call number as Meillerkarten 25 a.

Klobučarićs cartographic legacy has been restored and digitalised. Trobas (1971) wrote about its condition in the 1970s and the restoration procedure. It has been available online since the end of 2014 (URL 2). Klobučarić's cartographic depictions do not have titles, but Fritz Popelka ${ }^{6}$ compiled a list of the cartographic legacy based on the areas shown on individual depictions, and published the list in German (Popelka 1932). A list of contents relating to Croatia, in Croatian, can be found in (Klen 1975) and (Marković 1993), while the full list in Croatian appears in (Marković 2002). Klen (1975) says of sheet 76, "Mount Velebit from Bosanski Brod and Modruš to the coast from Rijeka to Senj”. This should read 'Brod na Kupi', not 'Bosanski Brod'. We established that this was a translation of the contents of the list given in (Popelka 1932). The error has been corrected on the Internet (URL 3).

All the cartographic depictions and written documents in Klobučarić's cartographic legacy can be viewed in high resolution on the Internet (URL 3). All the sheets are said to have originated between 1601 and 1605. Table 1 gives a list of the sheet contents which include one or more cartographic depictions relating to the area of Croatia. The texts of the contents of cartographic depictions shown in German are taken from the website of the Archives, where the Clobucciarich-Skizzen collection can be found (URL 3). We noted that the contents in German for certain sheets were incomplete, and sometimes contained errors. For example, for sheet 76 it says it shows Mount Velebit from Brod na Kupi and Modruš to the coast from Rijeka to Senj, but Velebit does not extend from Brod na Kupi. For sheet 98 it says that it shows the area as far as Split, but in fact it shows the area as far as Omiš.

\section{Klobučarić's Cartographic Depictions of the Kvarner Littoral}

Klobučarić's cartographic legacy includes a sketch (sheet 76) of the Kvarner Littoral from Rijeka to Sveti Juraj with the mainland hinterland (Fig. 1) and a map (sheet 98) of part of Croatia from Rijeka to Omiš with the mainland hinterland (Fig. 2).

We established that some Croatian researchers (Klen 1975; Marković 1993, 2002) published extracts of

${ }^{6}$ Fritz Popelka was employed at the Archives in 1919 and was the director from 1950 to 1955 (Posch 1974).

KiG No. 30, Vol. 17, 2018, https://doi.org/10.32909/kg.17.30.4 - 
Patentom nadvojvode Ferdinanda II., od 6. rujna 1603., Klobučariću se nalaže nastavak kartografskih radova, posao je bio proširen na cijelu Unutarnju Austriju. Patent je sačuvan u Klobučarićevoj ostavštini na listu 104a i 104b. Patentom nadvojvoda poziva podređene vlasti da Klobučariću u svakoj prilici ukažu spremnost na suradnju. Iz tog se patenta saznaje da se Klobučarić dobrovoljno javio za izradu karte (Marković 2002)4. Godine 1604.i 1605. svoju pažnju Klobučarić je usredotočio na Kranjsku i austrijski dio Istre (Popelka 1923; Klen 1974, 1975).

Posljednji tragovi Klobučarićeva djelovanja bilješke su i skice kao reagiranja na pismo koje mu je Martio Marchesetti uputio 26. kolovoza 1605. Pismo je sačuvano u Klobučarićevoj ostavštini na listu 107a i 107b. Sastanak kaptola štajersko-koruške augustinske provincije održan je 27. travnja 1606. Na tom je sastanku dan raspored svih redovnika u šest samostana, a među njima nema Klobučarića. Na osnovi navedenog, Klobučarić je umro između dva spomenuta datuma. ${ }^{5}$ Nakon Klobučarićeve smrti, njegovu imovinu među kojom je bila i kartografska ostavština, naslijedio je augustinski samostan u Rijeci. Ugovorom od 3. svibnja 1606. samostan na doživotno uživanje svu Klobučarićevu imovinu ustupa njegovu bratu Jurju. U ljeto iste godine kartografsku ostavštinu Klobučarićev brat predao je Unutarnjoaustrijskoj vladi (Innerösterreichische Regierung) te tražio isplatu zaslužbe svojega brata. U veljači 1607. Dvorska komora (Hofkammer) u Grazu zatražila je da se Petru Karalu isplati 50 talira koje je uručio Klobučarićevu bratu u ljeto 1606. (Popelka 1923, 1932; Laszowski 1937; Peruško 1958a; 1958b; Klen 1974, 1975; Marković 2002).

\subsection{Klobučarićeva kartografska ostavština}

$\mathrm{Na}$ internetskim stranicama Štajerskog zemaljskog arhiva $u$ Grazu nalaze se podaci o povijesti fonda Clobucciarich - Skizzen iz kojih se može saznati nastanak fonda. Tako se može pročitati da je Andreas von Meiller iz Kućnog, dvorskog i državnog arhiva (Haus-, Hof-, und Staatsarhiv) iz Beča istraživao fondove spisa u gradačkom Burgu od 28. kolovoza do 2. listopada 1846. Prema vlastitoj procjeni o važnosti spisa, izdvojio je one koje je trebalo isporučiti u Beč, a među njima su se nalazili i Klobučarićevi kartografski prikazi. U spomenuti Arhiv izdvojeni spisi stigli su krajem 1847. U Graz su Klobučarićevi kartografski prikazi vraćeni 1922. s još 49 svezaka (fascikla) i tada su bili dio posebnog fonda Meillerakten (Meillerovi spisi). Zbog skladištenja, Klobučarićevi

\footnotetext{
${ }^{4}$ Prijevod patenta na hrvatski jezik donosi Marković (2002).

${ }^{5}$ Marković (2002) piše da je Klobučarić umro u proljeće 1605. što je pogrešno.
}

kartografski prikazi odvojeni su od ostalih spisa navedenog fonda, te su postali posebni fond Clobucciarich Skizzen (URL 1). Treba napomenuto da Popelka (1923) navodi da je signatura Klobučarićeve ostavštine Meillerakten, Fasz. 25a, dok Peruško (1958a, 1958b) pogrešno navodi signaturu Meillerkarten 25a.

Klobučarićeva kartografska ostavština je restuarirana i digitalizirana. O stanju Klobučarićeve ostavštine 1970-ih godina i postupcima restauracije pisao je Trobas (1971). Od kraja 2014. kartografska ostavština dostupna je online (URL 2). Treba napomenuti da Klobučarićevi kartografski prikazi nemaju naslove, već je na osnovi područja prikazanoga na pojedinom kartografskom prikazu Fritz Popelka ${ }^{6}$ sastavio popis Klobučarićeve kartografske ostavštine te popis sadržaja listova na njemačkom jeziku objavio u radu (Popelka 1932). Popis sadržaja listova na hrvatskom jeziku koji se odnose na Hrvatsku nalaze se u radovima Klena (1975) i Markovića (1993), a popis sadržaja svih listova na hrvatskom jeziku dan je u radu (Marković 2002). Klen (1975) za list br. 76 piše „Velebitsko gorje od Bosanskog broda i Modruša do obale morske kod Rijeke i Senja“. Nije riječ o Bosanskom Brodu već o Brodu na Kupi. Utvrdili smo da je to prijevod za sadržaj navedenog lista koji je dan u radu (Popelka 1932). Treba napomenuti da je ta pogreška na internetu (URL 3) ispravljena.

Svi kartografski prikazi i pisani dokumenti iz Klobučarićeve kartografske ostavštine mogu se pregledavati u visokoj rezoluciji na internetu (URL 3). Za sve listove piše da su nastali u razdoblju 1601-1605. U tablici 1 donosimo popis sadržaja listova na kojima se nalazi jedan ili više kartografski(h) prikaz(a) koji se odnosi(e) na područje Hrvatske. Tekstovi sadržaja kartografskih prikaza na njemačkom jeziku preuzeti su s internetskih stranica Arhiva na kojima je dostupan fond Clobucciarich - Skizzen (URL 3). Uočili smo da su tekstovi sadržaja na njemačkom jeziku za pojedine listove nepotpuni, a ponekad i pogrešni. Tako npr. za list 76 piše da prikazuje planinu Velebit od Broda na Kupi i Modruša do obale od Rijeke do Senja, što je pogrešno, jer se Velebit ne prostire od Broda na Kupi. Za list 98 navedeno je da prikazuje područje do Splita, a zapravo prikazuje područje do Omiša.

\section{Klobučarićevi kartografski prikazi Kvarnerskog primorja}

U Klobučarićevoj kartografskoj ostavštini, od kartografskih prikaza na kojima je predočeno Kvarnersko primorje nalaze se skica (list 76) Kvarnerskog primorja

\footnotetext{
${ }^{6}$ Fritz Popelka zaposlio se u Arhiv 1919., dužnost direktora obnašao je 1950-1955. (Posch 1974).
} 


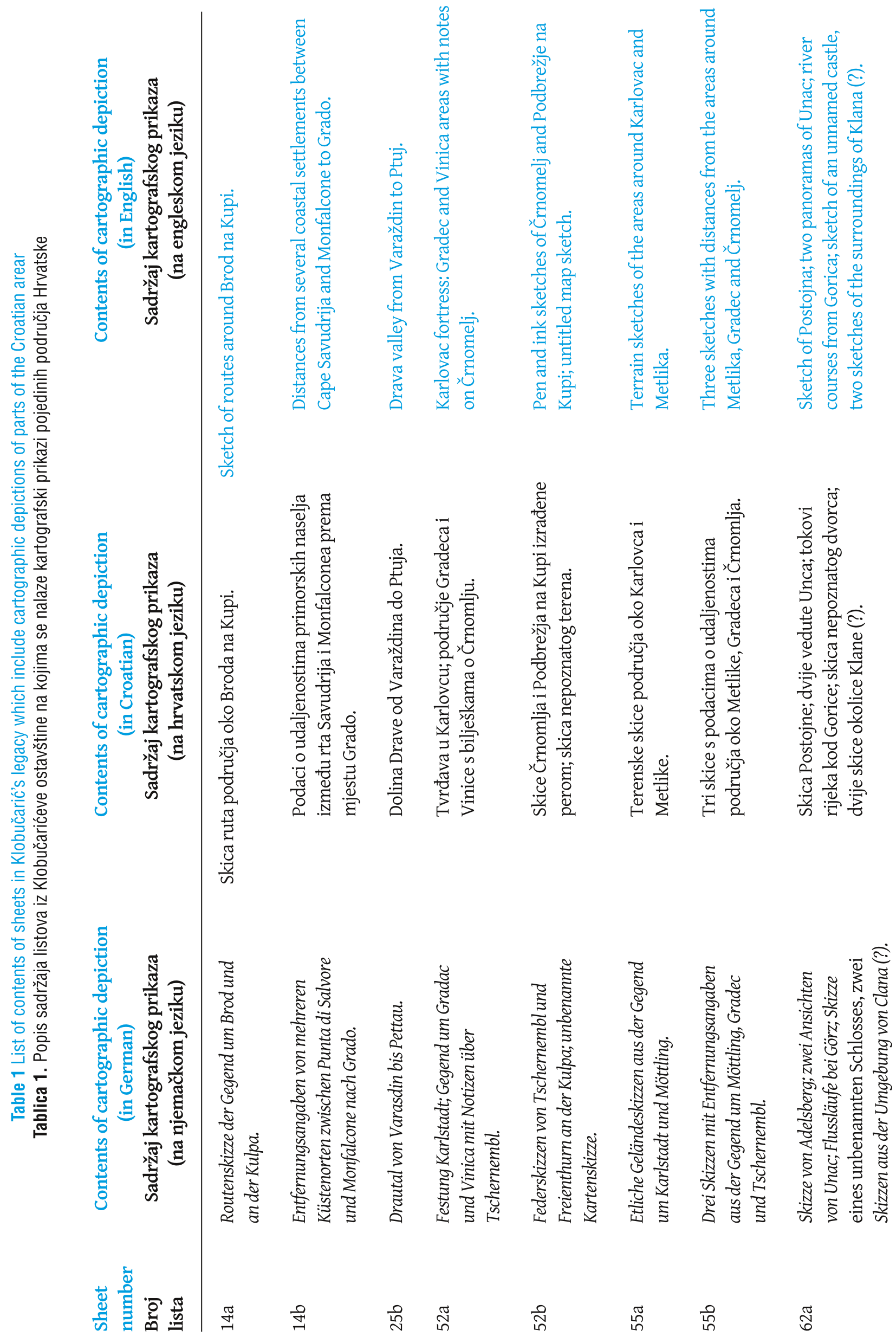




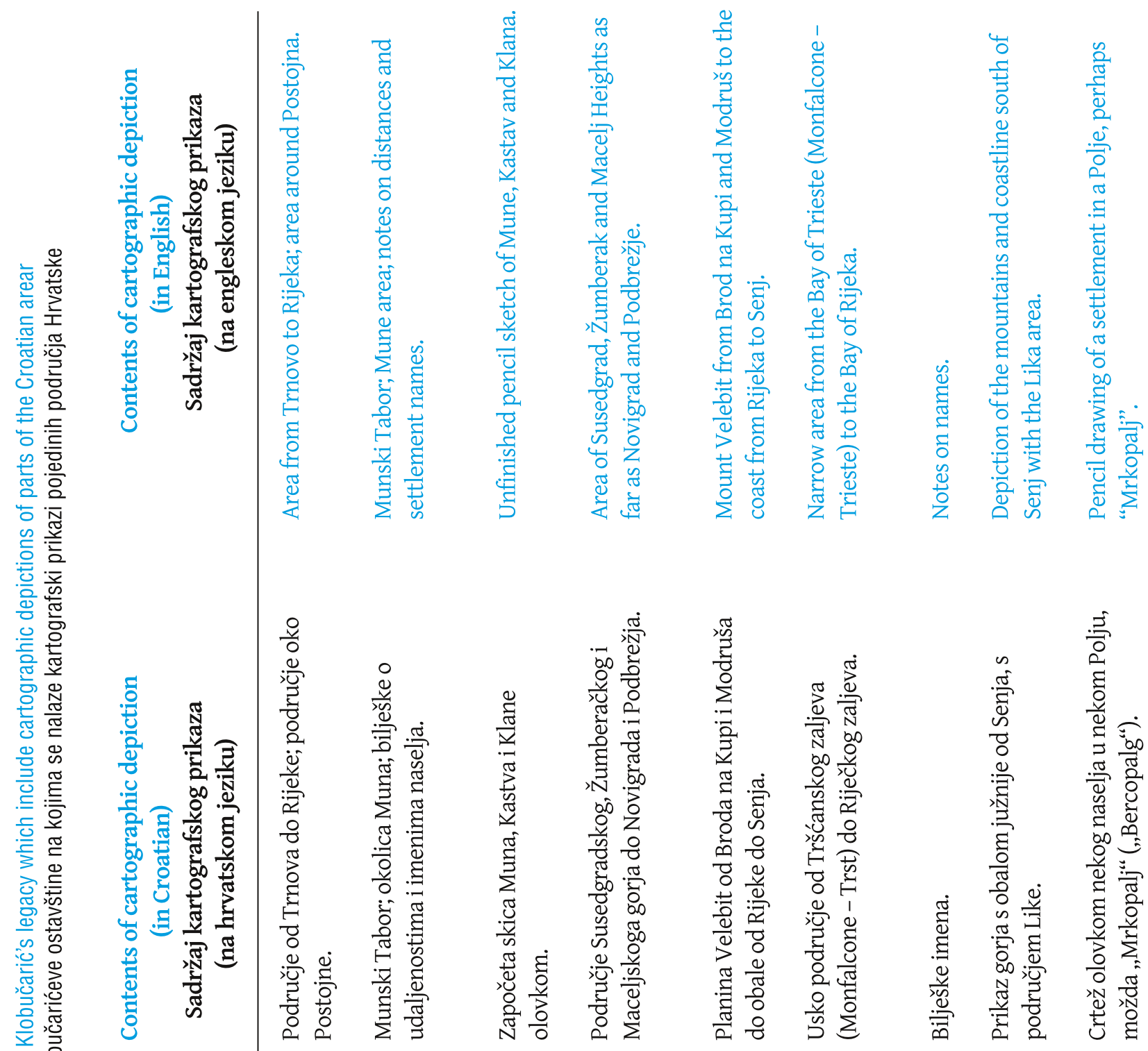

을

过 N.

क व

里

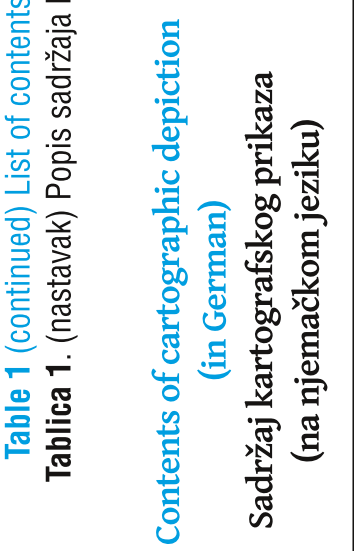

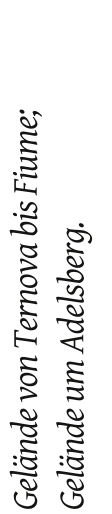

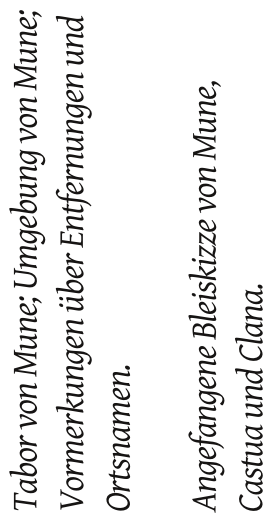

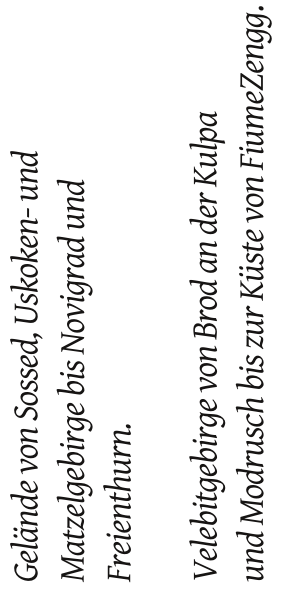

官

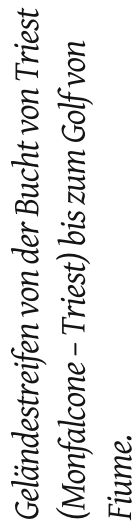

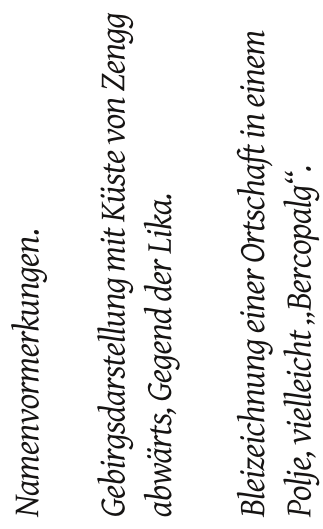

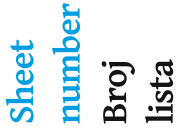

สิธี่

हुํำ 앙

$\therefore \quad$ வ

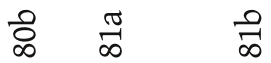




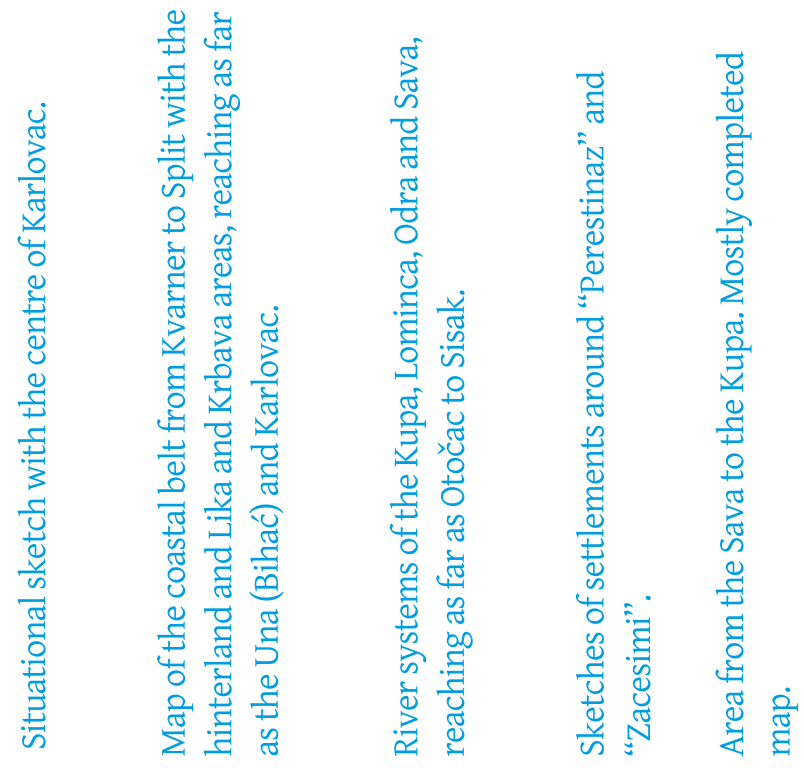

我

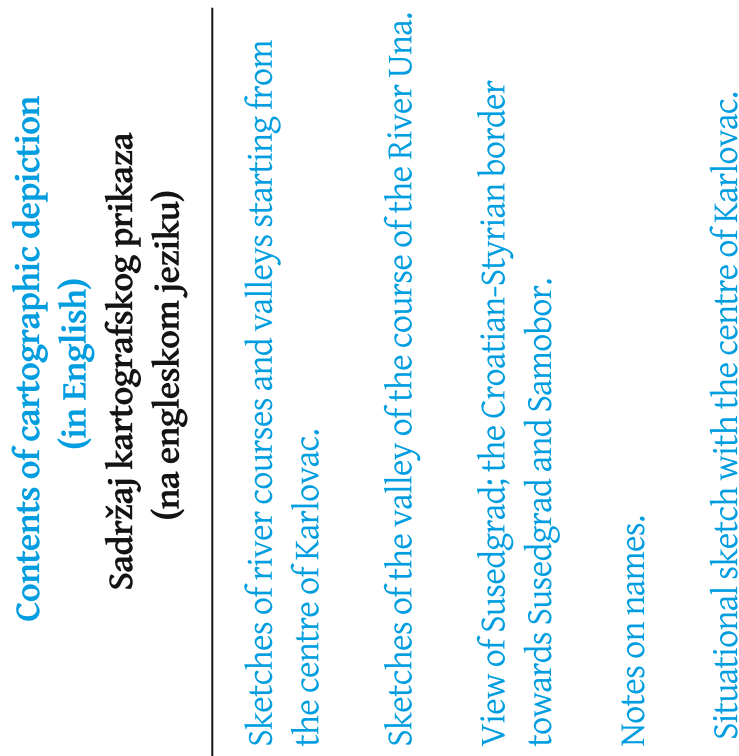

음 홍

을

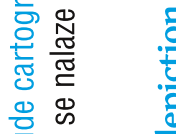

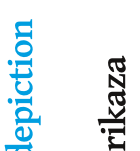

है वे है

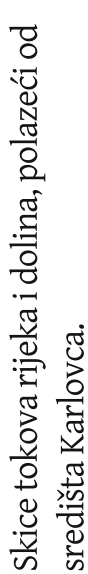

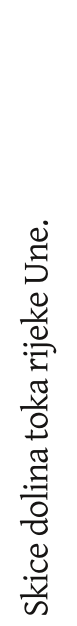

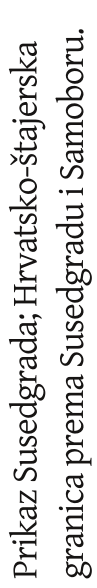

$\frac{\pi}{2}$

0
0
0
0
0
0

速

気 离

등

胥

응

on

듕 흉용

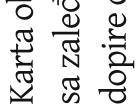

莡

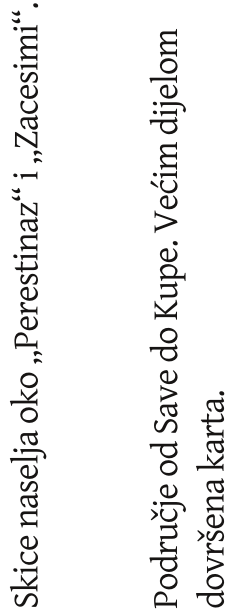

क

क ल

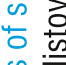

里

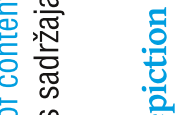

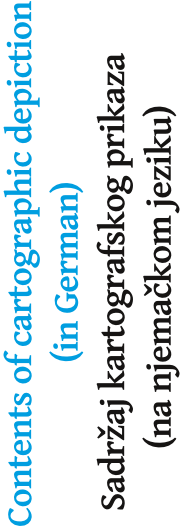

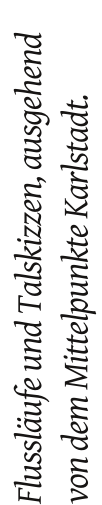

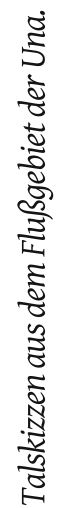

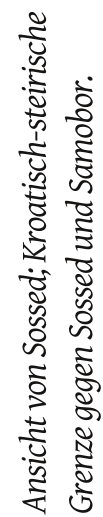

苛

เั้ รั

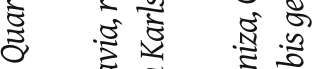
文卷

造 范

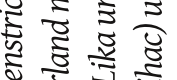

通产遥

政

ठँ

言

音

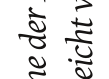

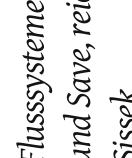

害

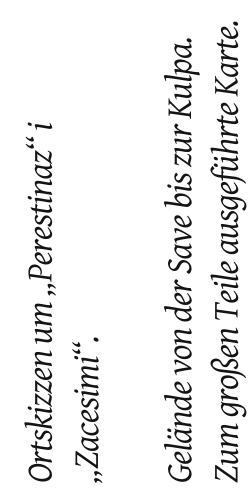

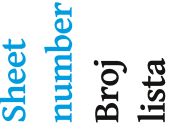

న్

ద్న

ڤ్

๙

ร็

영

$\stackrel{8}{9}$ 


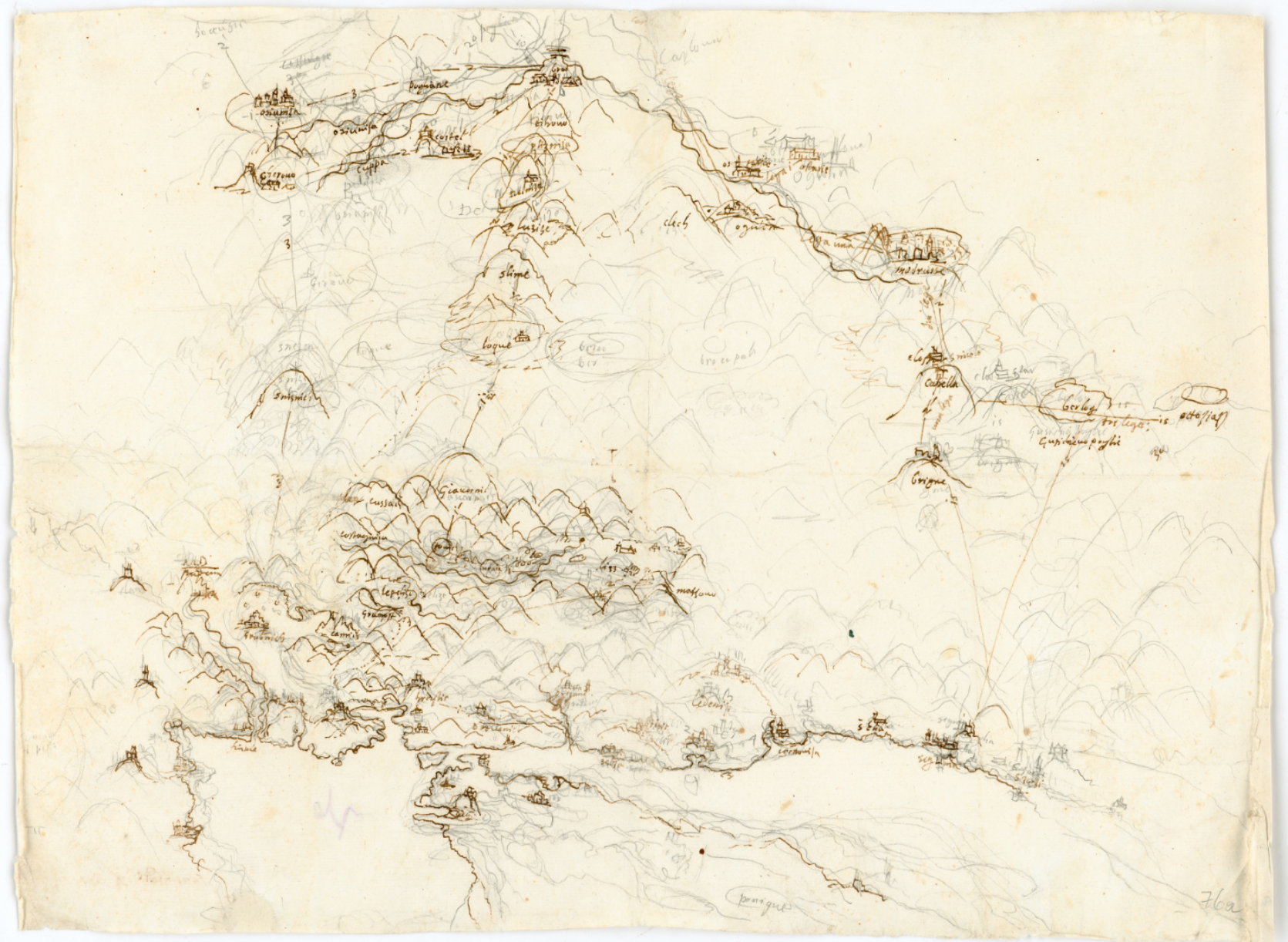

Fig. 1 Ivan Klobučarić, Sketch of the Kvarner Littoral from Rijeka to Sveti Juraj with the mainland hinterland, early 17th century (Steiermärkisches Landesarchiv, Graz, Clobucciarich - Skizzen collection, call no. Clobucciarich-076). The sketch is published with the permission of the Styrian Provincial Archives (Steiermärkische Landesarchiv) in Graz and may not be reproduced.

Slika 1. Ivan Klobučarić, Skica Kvarnerskog primorja od Rijeke do Sv. Jurja s kopnenim zaleđem, početak 17. stoljeća (Steiermärkisches Landesarchiv, Graz, fond Clobucciarich - Skizzen, sign. Clobucciarich-076). Skica se objavljuje uz dozvolu Štajerskoga zemaljskog arhiva (Steiermärkische Landesarchiv) u Grazu te se ne smije reproducirati.

od Rijeke do Sv. Jurja s kopnenim zaleđem (slika 1) i karta (list 98) dijela Hrvatske od Rijeke do Omiša s kopnenim zaleđem (slika 2).

Utvrdili smo da su pojedini hrvatski istraživači u svojim radovima (Klen 1975; Marković 1993, 2002) objavili isječke skice i karte ne navodeći da je to isječak. Uočili smo da su ti iscječci uređivani, dodavani su im okviri koji ne postoje u izvorniku, pojačavan je dio prikazanog sadržaja, uređivan je reljef. Na temelju toga, čitatelji bi mogli donijeti pogrešne zaključke o izvornicima. Dva isječka skice i isječak karte objavio je Klen (1975). Ispod isječaka skice piše „Ivan Klobučarić, predjeli od Broda na Kupi do Selaca..." i „Ivan Klobučarić, predjeli od Oštarija i Ogulina do Jurjeva kod Senja..... Na osnovi toga, čitatelji rada mogu zaključiti da je riječ o dvjema skicama što je pogrešno. Ispod isječka karte piše „Ivan Klobučarić, Hrvatska od Karlovca do Biograda na moru i Lošinja....". Međutim, na isječku nije prikazan dio do Biograda na Moru. Isječak skice i karte objavio je Marković (1993). Ispod isječka skice piše „Topografska skica Gorskog kotara, rad Ivana Klobučarića“. Na osnovi toga, čitatelji djela mogu zaključiti da je riječ o skici navedenog područja. Ispod isječka karte piše „Topografska skica Kvarnera s otocima Krk, Cres i Lošinj, rad Ivana Klobučarića“. Marković je dodao okvir tom isječku. Na osnovi teksta i dodanog okvira čitatelji djela mogu zaključiti da je riječ o skici navedenog područja što je pogrešno. O skici i karti detaljnije je pisao Marković (2002) te objavio repodukcije skice i karte te nekoliko isječaka karte. Treba napomenuti da su skica i karta te isječci karte uređivani, obrezani su im rubovi, dodan im je okvir koji ne postoji, pojačavane su linije pojedinih prikazanih objekata, uređivan je reljef.

$\mathrm{Na}$ internetskim stranicama Arhiva na kojima je dostupan fond Clobucciarich - Skizzen (URL 3), za skicu i 
sketche and map without indicating that it is an excerpt. We noticed that these extracts had been edited, with additional frames not present in the originals, and that some of the depicted contents had been emphasised and the relief edited. Based on this, readers might reach false conclusions about the originals. Klen (1975) published two extracts of a sketch and one map extract. Underneath the extracts of the sketch it says, "Ivan Klobučarić, areas from Brod na Kupi to Selce ..." and "Ivan Klobučarić, areas from Oštarije and Ogulin to Jurjevo at Senj ...". Based on this, readers might conclude that there are two sketches, which would be wrong. Underneath the map extract it says, "Ivan Klobučarić, Croatia from Karlovac to Biograd na Moru and Lošinj ...". However, the extract does not show the part as far as Biograd na Moru. Marković published an extract of a sketch and map (Marković 1993). Underneath the extract of the sketch it says, "Topographic sketch of Gorski Kotar by Ivan Klobučarić". Based on this, readers might conclude that this is a sketch of the given area. Underneath the section of the map it says, "Topographic sketch of Kvarner with the islands of Krk, Cres and Lošinj by Ivan Klobučarić". Marković added a frame to that section. Based on the text and the added frame, readers of the work might conclude that this was a sketch of given area, which would be wrong. Marković (2002) writes in more detail about the sketch and map, and provides reproductions of the sketch and map and several map extracts. It should be stressed that the sketch, map, and map extracts, have been edited. Their edges have been cut off and a frame added, while the lines of certain objects have been emphasised and the relief edited.

On the Archives website, which makes the Clobucciarich - Skizzen collection available (URL 3), it says that the sketch and map were drawn in pencil. We noticed that Klobučarić later erased, corrected and supplemented part of the contents, and also emphasised some contents in black ink and sepia. He wrote the name Ogulin in pencil on the right bank of the river which represented the River Dobra, and used sepia to correct it to the left bank. He wrote the name Senj in pencil, away from the coast, and corrected it in sepia on the coast. On the map, Rijeka and Senj were shown in pencil, while most other larger settlements were marked in sepia. $\mathrm{He}$ wrote toponyms on the islands of Cres, Lošinj and Rab in pencil, then erased them and emphasised some of them in ink, which makes identifying them more difficult.

Maps can be described using basic map elements (title, areas shown and orientation, purpose and intention, contents, time of production, author, publisher, printer, print run, users, legend, mathematical elements, index or list of objects, source of information, and means of production) and secondary ones (map frame, text with explanation, and people responsible). Since Klobučarić's cartographic depictions of the Kvarner Littoral do not contain most of these elements, we will not describe them in this way in this paper, but will provide brief descriptions.

The sketch and map have no titles or author's name, and the time of production is missing. The sketch covers parts of modern-day Gorski Kotar, the Ogulin-Modruš valley and Lika, part of the eastern coast of Istria and the Kvarner Littoral from Rijeka to Sveti Juraj with the mainland hinterland. The map shows part of the eastern coast of Istria and the north-eastern shore of the Adriatic Sea from Rijeka to Omiš with the mainland hinterland, parts of the Lika, Krbava and Gorski Kotar areas, and the areas around Karlovac, Bihać and Glamoč. In addition, the sketch shows part of the island of Krk, but does not name it, while the map shows all the large and some of the small Kvarner islands, an unnamed island in the Zadar archipelago and several unnamed smaller islands in the Šibenik archipelago. Rab and Pag are named, while Krk, Cres and Lošinj are not, though the names of the towns of Cres and Lošinj appear. We discovered that the locations of the islands of Silba and Olib had been exchanged. The contours of the islands are not well drawn in relation to their actual shapes and their indentation is not reproduced well. The coastlines are simplified, omitting most bays and coves. Krk and Cres are too large, and Cres and Lošinj much wider than in reality. Pag is depicted without its major peninsulas, bays and coves. Rab is shown more reliably than the other islands.

There is a simple wind rose on the sketch and map showing the four points of the compass. Klobučarić uses Italian terms for wind directions: north $-\mathrm{T}$ (Tramontana); south - O (Ostro); east - L (Levante); and west - P (Ponente). Based on the wind rose, the sketch is oriented to the north (the wind rose is hard to find, above Lič) and the map to the north-east. However, we discovered that not all the areas shown on the sketch and map were oriented properly. On the sketch, Otočac is north-east of Senj, and is east of Senj on the map, which is incorrect.

The sketch measures $43 \times 32 \mathrm{~cm}$, and the map $97 \times 43$ $\mathrm{cm}$ (folio format). On the map, underneath the depictions of Silba and Olib there are two graphical scales giving the units for length in German leagues or miles (Lega Todesca) and Italian miles (Miglia Italiana). Based on these scales, we determined the numerical scale of the map (about 1:424,000). Marković (2002) and Crljenko and Šeparović (2009) considered that the scale of map is about 1:300,000. On the sketch and map, distances are marked

KiG No. 30, Vol. 17, 2018, https://doi.org/10.32909/kg.17.30.4 - - 


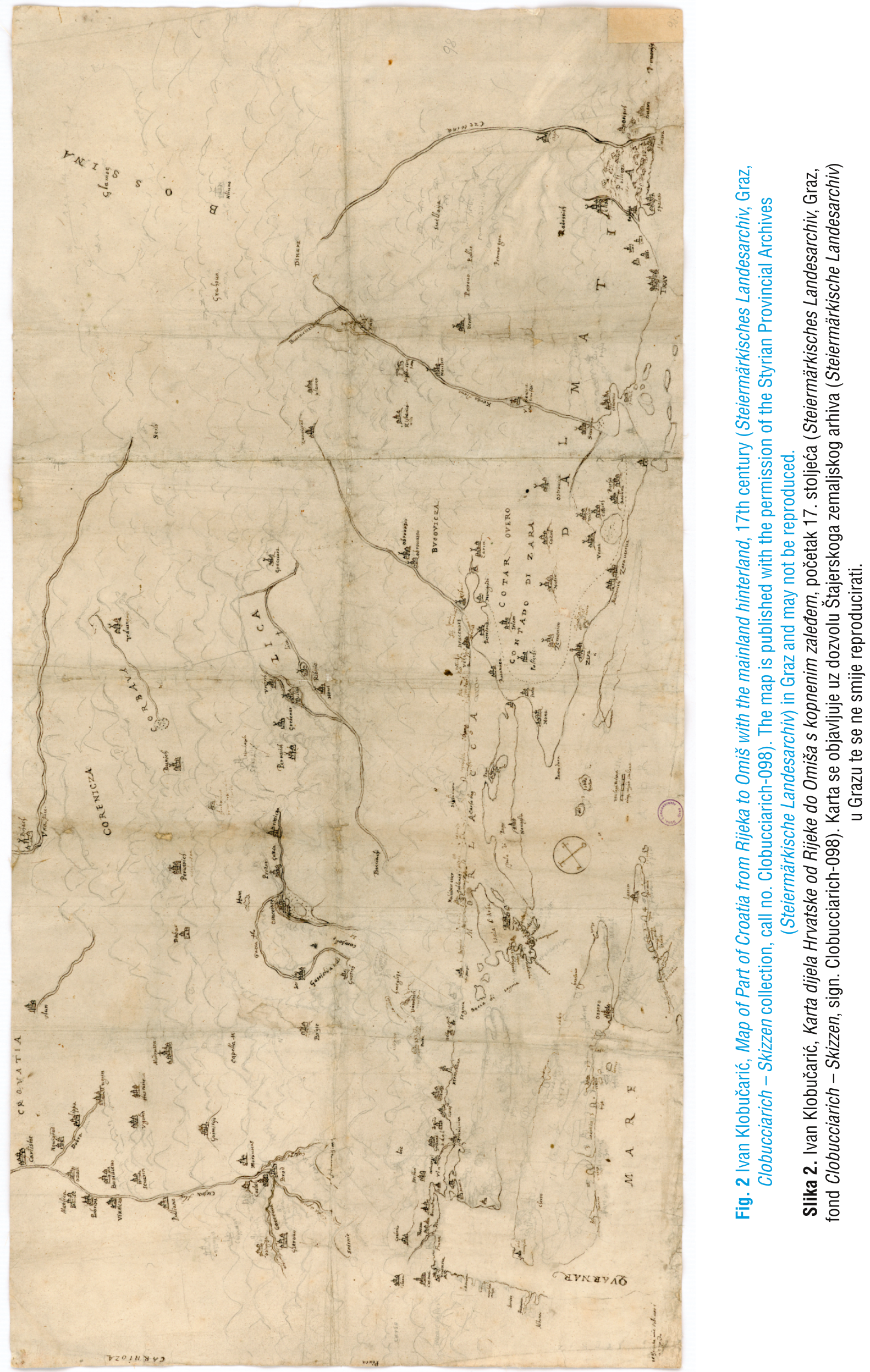




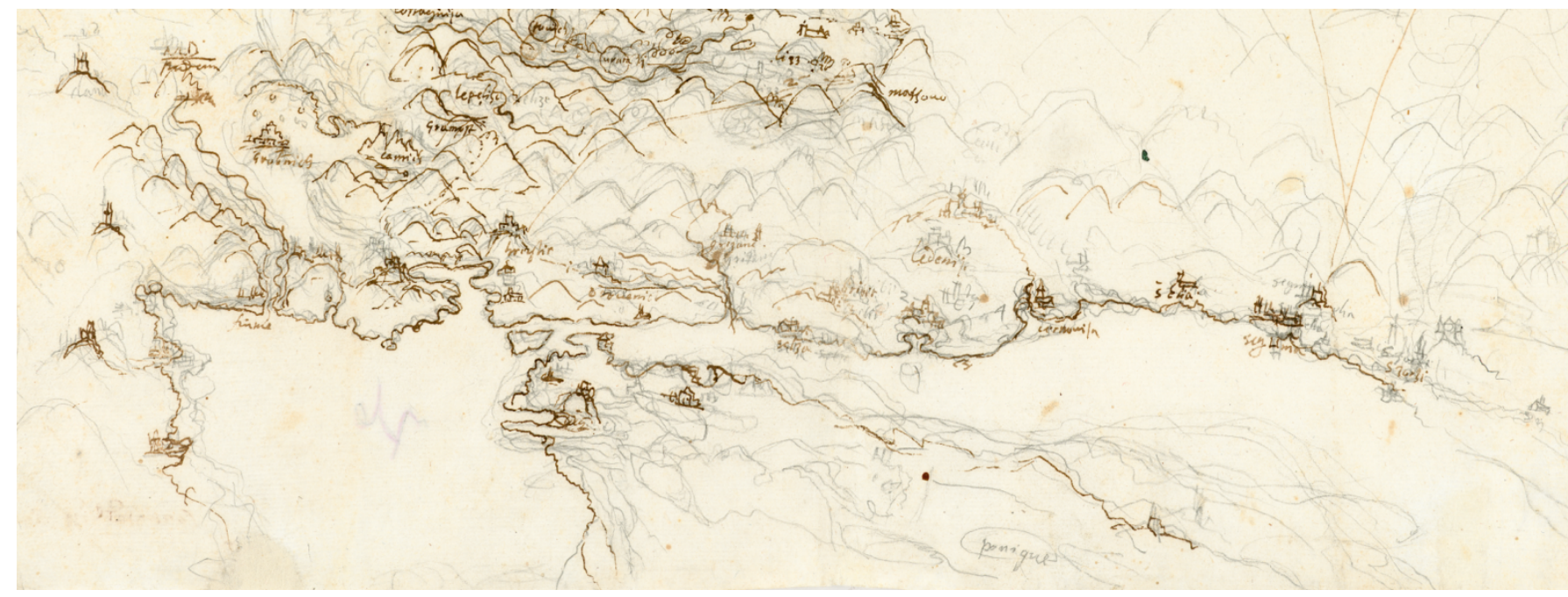

Fig. 3 Ivan Klobučarić, Sketch of the Kvarner Littoral from Rijeka to Sveti Juraj with the mainland hinterland, fragment, early 17th century (Steiermärkisches Landesarchiv, Graz, Clobucciarich - Skizzen collection, call no. Clobucciarich-076)

Slika 3. Ivan Klobučarić, Skica Kvarnerskog primorja od Rijeke do Sv. Jurja s kopnenim zaleđem, isječak, početak 17. stoljeća (Steiermärkisches Landesarchiv, Graz, fond Clobucciarich - Skizzen, sign. Clobucciarich-076)

between settlements and the number of German leagues or miles written in Italian in words or numerals. So along the coastlines of Cres, Lošinj and Rab there are numbers which may indicate distances between bays. We noticed that the distance between Senj and Otočac on the sketch was 30, but on the map it was 35 .

The sketch and map both show basic topographic elements such as settlements, hydrography, relief and toponyms, while only the map shows boundaries (only one is marked) but does not show roads or vegetation. The map has a large number of toponyms, mostly settlements (oeconyms), hills and mountains (oronyms), land water bodies (hydronyms), islands (nesonyms) and regions and areas (horonyms).

Settlements are represented most on the map. It does not include a legend, but we noted different signs used to mark fortified settlements, fortifications, monasteries and churches. Two signs included a cross, denoting the seat of an archbishop (with a double cross) or bishop (with a single cross). Settlements under Turkish control had a half-crescent in the sign. Perušić was depicted and named in two different places; one near Dabar as the seat of the bishop (we do not know whether there was really a settlement of that name in this location), and the other near Grebenar, with a half-crescent, on the site of present-day Perušić. Obrovac was shown twice, close together, with slight variations in the spelling of the name. Some settlements were named but not given signs, for example Radošić and the settlements on the eastern coast of Istria. The names of mountains are written like the names of settlements without signs.
On the map, the area from Bakarac to Novi Vinodolski is called Vinodol for the first time on Klobučarić's map. The toponym Morlacca is written on the sea and may indicate the Morlach Channel (Velebit Channel) or the region of Morlachia. The Gates of Senj (Bocca di Segnia) are named. The border with the Ottoman Empire is marked with a broken line from Novigrad to Skradin. The relief is shown using molehills. On the sketch, river courses are shown with single wavy lines, but on the map, the lines are double. The meandering of river flows are drawn arbitrarily. On the sketch, only the River Kupa is shown and named, while the Dobra, Rječina and Dubračina are shown but not named. On the map, the Kupa, Kupica, Dobra, Gacka and Una are all shown and named using the abbreviation flu., while the word fiume appears by the name of the River Krka and the letter $f$ is written by the name of the River Lika. The Rječina, Dubračina, Zrmanja, Butišnica, Jadro and Cetina are all shown but not named. Lake Vransko and Lake Prokljansko are both shown but not named. Otočac is shown on an islet in the middle of the River Gacka, surrounded by marshes.

\subsection{Settlements of the Kvarner Littoral on Klobučarić's sketch and map}

Since the sketch was produced during field work and most of the contents were later supplemented, it is difficult to read the signs showing individual settlements and their names. The sketch shows a smaller area of the Kvarner Littoral than that on the map. According to Marković (2002) and Crljenko and Šeparović (2009),

KiG No. 30, Vol. 17, 2018, https://doi.org/10.32909/kg.17.30.4 - - 


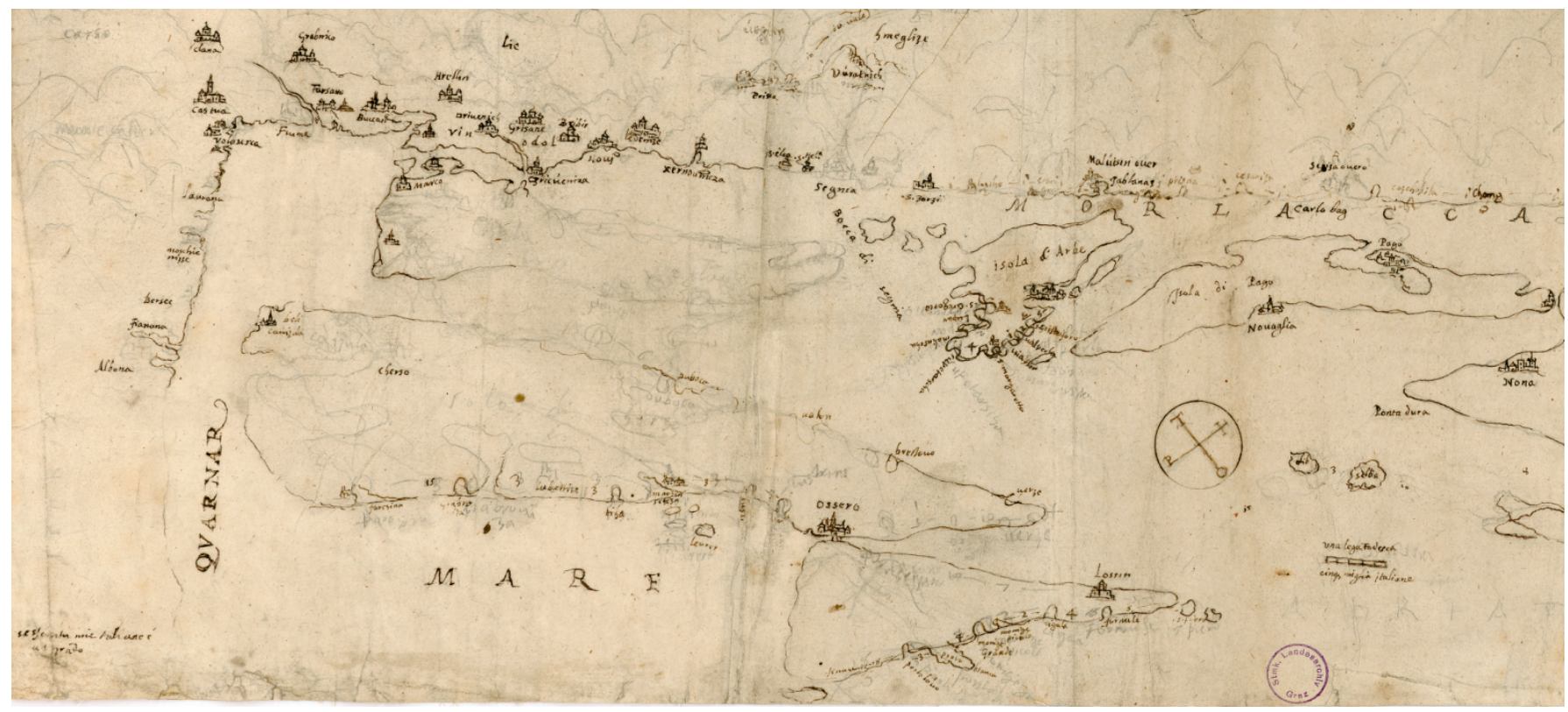

Fig. 4 Ivan Klobučarić, Map of Part of Croatia from Rijeka to Omiš with the mainland hinterland, fragment, 17th century (Steiermärkisches Landesarchiv, Graz, Clobucciarich - Skizzen collection, call no. Clobucciarich-098)

Slika 4. Ivan Klobučarić, Karta dijela Hrvatske od Rijeke do Omiša s kopnenim zaleđem, isječak, početak 17. stoljeća (Steiermärkisches Landesarchiv, Graz, fond Clobucciarich - Skizzen, sign. Clobucciarich-098)

kartu piše da su izrađene olovkom. Uočili smo da je Klobučarić dio sadržaja na skici i karti naknadno brisao, popravljao i dopunjavao, a dio sadržaja pojačavao je perom (crnilom, sepijom). Tako je na skici olovkom Ogulin imenovao s desne strane rijeke koja bi trebala predstavljati rijeku Dobru, a sepijom je ispravio prikazavši ga s lijeve strane rijeke. Ime Senja napisao je olovkom odmaknuto od obale, a sepijom uz obalu. Na karti su Rijeka i Senj ostali prikazani olovkom, dok je većina ostalih većih naselja označena crnilom. Toponime na otocima Cres, Lošinj i Rab pisao je olovkom, a potom ih brisao, a neke pojačao perom što otežava njihovo identificiranje.

Neka karta može se opisati s pomoću osnovnih (naslov, područje prikaza i orijentacija karte, svrha i namjena karte, sadržaj karte, vrijeme izrade, autor, izdavač, tisak, naklada, korisnici, tumač znakova, matematički elementi, indeks ili popis objekata, izvor podataka, način izrade karte) i sporednih (okvir karte, tekst s objašnjenjem, zaslužne osobe) elemenata karte.

S obzirom na to da Klobučarićevi kartografski prikazi Kvarnerskog primorja ne sadrže većinu navedenih elemenata, u ovom radu nećemo ih opisati s pomoću tih elemenata već donosimo njihove skraćene opise.

Skica i karta nemaju naslov, ime autora i oznaku vremena nastanka. Skica obuhvaća dijelove današnjih područja Gorskog kotara, Ogulinsko-modruške udoline i Like, dio istočne obale Istre i obalu Kvarnerskog primorja od Rijeke do Sv. Jurja s kopnenim zaleđem. Na karti su prikazani dio istočne obale Istre i sjeveroistočne obale
Jadranskog mora od Rijeke do Omiša s kopnenim zaleđem, dijelovi područja Like, Krbave i Gorskog kotara te područja oko Karlovca, Bihaća i Glamoča. Osim navedenih područja, na skici je prikazan dio otoka Krka, ali nije imenovan, dok su na karti prikazana sva veća i nekoliko manjih kvarnerskih otoka, jedan neimenovani otok u zadarskom arhipelagu i nekoliko neimenovanih manjih otoka u šibenskom arhipelagu. Imenovani su otoci Rab i Pag, dok otoci Krk, Cres i Lošinj nisu, ali su na Cresu i Lošinju prikazana i imenovana naselja Cres i Lošinj. Utvrdili smo da su zamijenjeni položaji otoka Silbe i Oliba. Oblici otoka u odnosu na njihove stvarne oblike, kao i njihove razvedenosti, nisu dobro predočeni. Obalne crte otoka su pojednostavljene, izostavljena je većina njihovih zaljeva i uvala. Otoci Krk i Cres prikazani su preuvećano, a Cres i Lošinj mnogo širim nego što su u stvarnosti. Pag je prikazan bez svojih važnijih poluotoka, zaljeva i uvala. Rab je prikazan vjerodostojnije od ostalih otoka.

Na skici i karti nalazi se jednostavna ruža vjetrova, na kojoj su označena samo četiri smjera. Za oznaku smjerova vjetrova Klobučarić se služio talijanskom terminologijom: sjever - T (Tramontana), jug - O (Ostro), istok - L (Levante), zapad - P (Ponente). Na osnovi ruža vjetrova, skica je orijentirana prema sjeveru (ruža vjetrova je teško prepoznatljiva, nalazi se iznad Liča), a karta prema sjeveroistoku. Međutim, utvrdili smo da sva prikazana područja na skici i karti nisu orijentirana kao što bi trebala. Tako se na skici Otočac nalazi sjeveroistočno od Senja, a na karti istočno što je pogrešno. 
Table 2 Geographic names (toponyms) in the Kvarner Littoral on four maps, with their contemporary names

Tablica 2. Geografska imena (toponimi) Kvarnerskog primorja sa četiriju karata i njihova suvremena imena

Geographic name on the map

Geografsko ime na karti

$\begin{array}{llll}\text { Fernando } & \text { Iohannes } & \text { Augustin } & \text { Ivan } \\ \text { Bertelli } & \text { Sambucus } & \text { Hirschvogel } & \text { Klobučarić } \\ \text { Fernanda } & \text { Iohannesa } & \text { Augustina } & \text { Ivana } \\ \text { Bertellija } & \text { Sambucusa } & \text { Hirschvogela } & \text { Klobučarića }\end{array}$

\begin{tabular}{|c|c|c|c|c|}
\hline Albona & & & Albona & Labin \\
\hline \multirow[t]{6}{*}{ Fianona } & Fianona & & Fianona & Plomin \\
\hline & Barsez & & Bersec & Brseč \\
\hline & Moseniza & & Moschienizze & Mošćenice \\
\hline & Laurano & & Laurano & Lovran \\
\hline & Valoscka & & Volousca & Volosko \\
\hline & Chasta & & Castua & Kastav \\
\hline \multirow[t]{3}{*}{ Fiume } & $\begin{array}{l}\text { S. Veit am } \\
\text { pflaum }\end{array}$ & S. Veit & Fiume & Rijeka \\
\hline & Tersat & Tersacz & Tarsatto & Trsat \\
\hline & S. Martin & & & Martinšćica \\
\hline \multirow{5}{*}{$\begin{array}{l}\text { Bocani } \\
\text { Boccarizo }\end{array}$} & Bachri & & Buccari & Bakar \\
\hline & & & & Bakarac \\
\hline & Cralin & & Hrellin & Hreljin \\
\hline & Treuemr & Drisenik & Driuenich & Drivenik \\
\hline & Grisna & Gerane & Grisane & Grižane \\
\hline Cernouiza & & Wackaniza & Czricueniza & Crikvenica \\
\hline \multirow[t]{6}{*}{ Berbir } & Wreuier & & Bribir & Bribir \\
\hline & Nouig & Noui & Noui & Novi Vinodolski \\
\hline & Ledeniza & Ledenicz & Ledenize & Ledenice \\
\hline & & & Xernouicza & Žrnovnica \\
\hline & & & Silia & Sibinj \\
\hline & & & S. Hela & Sveta Jelena \\
\hline \multirow[t]{8}{*}{ Segna } & Zegna & Zeng & Segnia & Senj \\
\hline & & S. Iorg & S. Zorzi & Sveti Juraj \\
\hline & & Starigrat & & Starigrad \\
\hline & Maluesin & Iablanaz & $\begin{array}{l}\text { Moluisin } \\
\text { ouer Jablanaz }\end{array}$ & Jablanac \\
\hline & & & Prisna & Prizna \\
\hline & & & Cesariza & Cesarices \\
\hline & & Sckrisacz & Scriza ouero & Karlobag \\
\hline & & & Carlobag & \\
\hline \multirow[t]{6}{*}{ Veia } & Velger & Welga & & $\begin{array}{l}\text { Krk - island } \\
\text { Krk - otok }\end{array}$ \\
\hline & Veia & Wegla & & $\begin{array}{l}\text { Krk - settlement } \\
\text { Krk-naselje }\end{array}$ \\
\hline & & $\begin{array}{l}\text { S Maria de } \\
\text { capite }\end{array}$ & & $\begin{array}{l}\text { Church of St. Mary } \\
\text { (Marija), Glavotok } \\
\text { crkva sv. Marije, Glavotok }\end{array}$ \\
\hline & $\begin{array}{l}\text { Castel } \\
\text { Muschio }\end{array}$ & Castel marco & Marco & Omišalj \\
\hline & Dobrigno & Dowranin & & Dobrinj \\
\hline & Verbenicho & Ferwenick & & Vrbnik \\
\hline
\end{tabular}

Contemporary geographic name Suvremeno geografsko ime

Labin

Brseč

Mošćenice

Lovran

Rijeka

Trsat

Bakar

Hreljin

Drivenik

Crikvenica

Ledenice

Sveta Jelena

Starigrad

Jablanac 
Table 2 (continued) Geographic names (toponyms) in the Kvarner Littoral on four maps, with their contemporary names

Tablica 2. (nastavak) Geografska imena (toponimi) Kvarnerskog primorja sa četiriju karata i njihova suvremena imena

\begin{tabular}{|c|c|c|c|c|}
\hline \multicolumn{5}{|c|}{ Geographic name on the map } \\
\hline Fernando & Iohannes & Augustin & Ivan & $\begin{array}{l}\text { Contemporary } \\
\text { geographic name }\end{array}$ \\
\hline Bertelli & Sambucus & Hirschvogel & Klobučarić & Suvremeno geografsko \\
\hline Fernanda & Iohannesa & Augustina & Ivana & ime \\
\hline \multirow[t]{4}{*}{ Bertellija } & Sambucusa & Hirschvogela & Klobučarića & \\
\hline & Weske & Welka & & Baška \\
\hline & S.M.de & & & Church of St. Mary \\
\hline & Kasion & & & $\begin{array}{l}\text { (Marija), Košljun } \\
\text { crkva sv. Marije, Košljun }\end{array}$ \\
\hline Sansego & Sansig & & & Susak \\
\hline \multirow[t]{2}{*}{ Cherso } & Kherscher & Kerssy & & Cres - island \\
\hline & & & & Cres - otok \\
\hline \multirow[t]{13}{*}{ Cherso } & Cherso & & Cherso & Cres - settlement \\
\hline & & & & Cres - naselje \\
\hline & S. Lorenzo & & & Sveti Lovreč \\
\hline & Cao Ißola & & Beli Canisola & Beli \\
\hline & S. Nicolo & & & Porozina \\
\hline & & & Farizina & $\begin{array}{l}\text { Porozina Bay } \\
\text { uvala Porozina }\end{array}$ \\
\hline & S. Tomaso & & & Pernat? \\
\hline & Lubenice & & Lubenize & Lubenice \\
\hline & & & Tiha & $\begin{array}{l}\text { Tiha Bay } \\
\text { uvala Tiha }\end{array}$ \\
\hline & & & Martinschiza & $\begin{array}{l}\text { Martinšćica Bay } \\
\text { uvala Martinšćica }\end{array}$ \\
\hline & & & Uerze & $\begin{array}{l}\text { Bay? } \\
\text { uvala? }\end{array}$ \\
\hline & & & Duboca & Dubovica Bay? \\
\hline & & & & Uvala Dubovica? \\
\hline Osero & Ossero & Osero & Ossero & Osor \\
\hline \multirow[t]{14}{*}{ Osero } & Lezin & & & Lošinj \\
\hline & Lezin & & Lossin & Mali Lošinj \\
\hline & & & Fornule & Bay? \\
\hline & & & Cigula & $\begin{array}{l}\text { uvala! } \\
\text { Čikat Bay } \\
\text { uvala Čikat }\end{array}$ \\
\hline & & & Monige & Bay? \\
\hline & & & picule & uvala? \\
\hline & & & Monige & Bay? \\
\hline & & & grande & uvala? \\
\hline & & & Ponvabianca & $?$ \\
\hline & & & Portolouo & $\begin{array}{l}\text { Bay? } \\
\text { uvala? }\end{array}$ \\
\hline & S. Nicolo & & & Sveti Nikola \\
\hline & Preuic & Paruy & & Prvić \\
\hline & Dreuenik & & & $\begin{array}{l}\text { Island? } \\
\text { otok? }\end{array}$ \\
\hline & Goly & Iolij & & Goli otok \\
\hline
\end{tabular}


Table 2 (continued) Geographic names (toponyms) in the Kvarner Littoral on four maps, with their contemporary names

Tablica 2. (nastavak) Geografska imena (toponimi) Kvarnerskog primorja sa četiriju karata i njihova suvremena imena

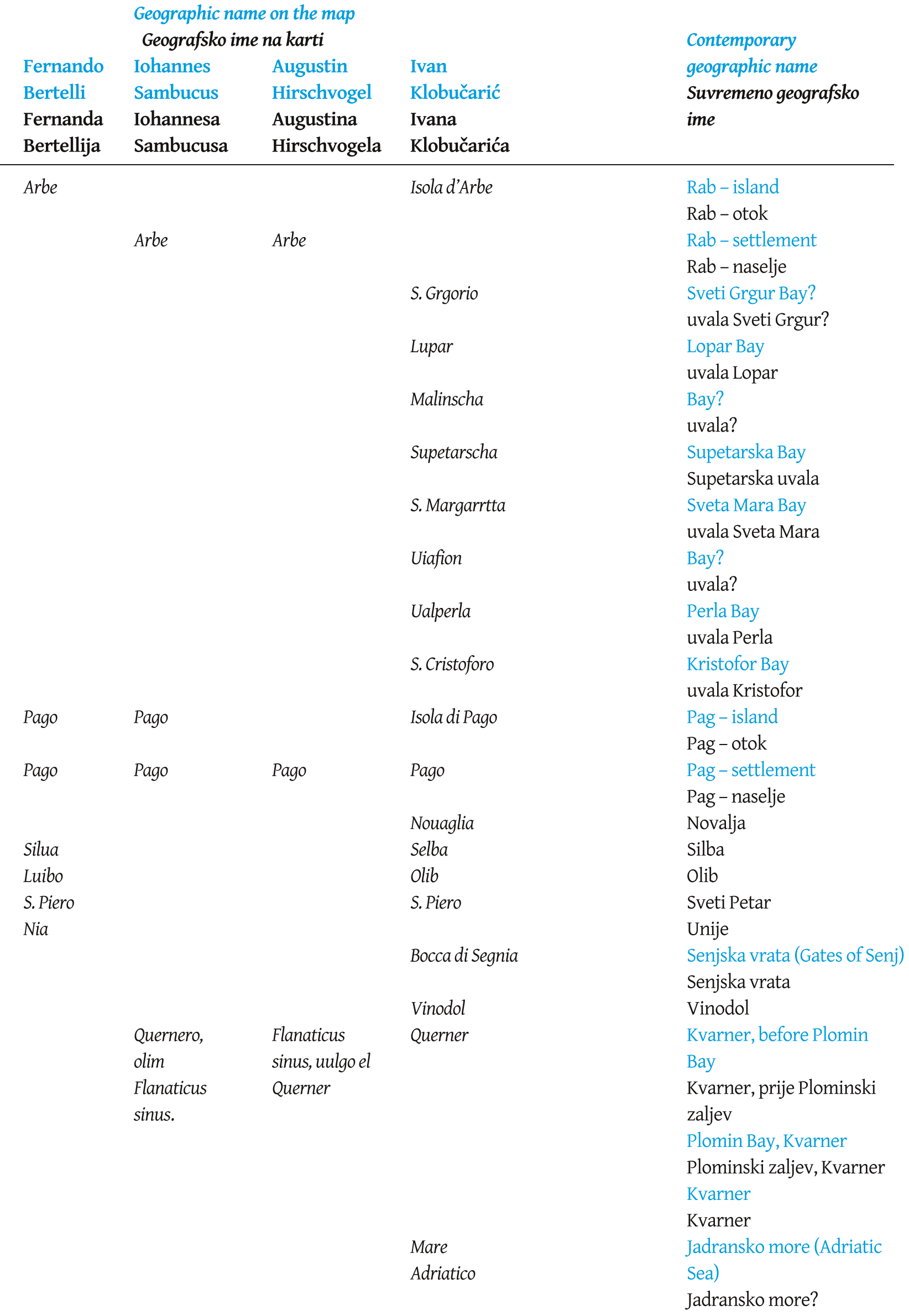


Dimenzije skice su $43 \times 32 \mathrm{~cm}$, a dimenzije karte $87 \times 43$ $\mathrm{cm}$ (pripada skupini folioformata). Na karti ispod prikaza otoka Silbe i Oliba nalaze se dva grafička mjerila na kojima su jedinične mjere za duljine u njemačkim ligama ili miljama (Lega Todesca) i talijanskim miljama (Miglia Italiana). Na osnovi grafičkih mjerila odredili smo numeričko mjerilo karte koje iznosi oko 1:424 000. U radovima (Marković 2002) i (Crljenko i Šeparović 2009) piše da je mjerilo karte oko 1:300 000. Na skici i karti između pojedinih naselja označene su udaljenosti, uz iscrtanu linju upisan je broj njemačkih liga ili milja na talijanskom jeziku, riječima ili brojkama. Tako se uz obale otoka Cresa, Lošinja i Raba mogu vidjeti brojevi koji bi mogli označavati udaljenosti između pojedinih uvala spomenutih otoka. Uočili smo da na skici za udaljenost između Senja i Otočca piše 30, a na karti 35.

Od osnovnih topografskih elemenata, na skici i karti prikazana su naselja, hidrografija i reljef te toponimi, dok su granice prikazane samo na karti (označena samo jedna granica), a prometnice i vegetacija nisu. Karta sadrži veliki broj toponima, među kojima je najveći broj imena naselja (ojkonima), zatim imena gora i planina (oronima), kopnenih voda (hidronima), otoka (nesonima) te regija i područja (horonima).

Naselja su najzastupljenija na karti. Karta ne sadrži tumač znakova, ali smo uočili nekoliko različitih znakova koji bi mogli označavati naselja s utvrdom, kaštelom, samostanom i crkvom. Postoje dva znaka koja sadrže križ, označavaju sjedišta nadbiskupija (znak s dvostrukim križem) i biskupija (znak s jednostrukim križem). Naselja koja su se nalazila na području pod turskom vlašću u znaku imaju polumjesec. Utvrdili smo da je na dva različita mjesta prikazan i imenovan Perušić, jednom u blizini Dabra kao sjedište biskupije (nije nam poznato je li na tom položaju postojalo naselje $s$ tim imenom), a drugi puta blizu naselja Grebenar sa znakom koji sadrži polumjesec što zapravo prikazuje današnji Perušić. Obrovac je prikazan dvaput jako blizu i imenovan s malom razlikom u pisanju imena. Neka naselja su imenovana, ali nemaju znak, npr. Radošić i naselja na istočnoj obali Istre. Pisanje imena planina ne razlikuje se od pisanja imena naselja bez znaka.

Na karti je područje od Bakarca do Novog Vinodolskog označeno imenom Vinodol koje je prvi puta zabilježeno na Klobučarićevoj karti. Toponim Morlacca upisan je na moru, što bi mogao označavati Morlački kanal (Velebitski kanal) ili regiju Morlakiju. Imenovana su Senjska vrata (Bocca di Segnia). Granica s Osmanskim Carstvom označena je crtkanom linijom od Novigrada do Skradina. Reljef je prikazan metodom krtičnjaka. $\mathrm{Na}$ skici su tokovi rijeka prikazani jednostrukim krivudavim linijama, a na karti dvostrukim linijama. Skretanja tokova rijeka nacrtana su proizvoljno. Na skici je prikazana i imenovana samo rijeka Kupa, a prikazane su i rijeke Dobra, Rječina i Dubračina, ali nisu imenovane. $\mathrm{Na}$ karti su prikazane i imenovane rijeke Kupa, Kupica, Dobra, Gacka i Una koje uz ime imaju i kraticu flu., uz ime rijeke Krke nalazi se riječ fiume, a slovo f piše kod imena rijeke Like. Prikazane su i rijeke Rječina, Dubračina, Zrmanja, Butišnica, Jadro i Cetina, ali nisu imenovane. $\mathrm{Na}$ karti su označani Vransko i Prokljansko jezero bez njihovih imena. Otočac je prikazan na otočiću usred rijeke Gacke, a oko njega močvara.

\subsection{Naselja Kvarnerskog primorja na Klobučarićevoj skici i karti}

Budući da je skica nastala na terenu, a većina sadržaja je dopunjavana što otežava prepoznavanje znakova za prikaz pojedinih naselja kao i njihovih imena. Na skici je prikazano manje područje Kvarnerskog primorja u usporedbi s područjem prikazanim na karti. Prema Markoviću (2002) te Crljenko i Šeparović (2009), Klobučarić je kartu izradio u razdoblju 1590-1600. za potrebe protuturske obrane te je karta dopunjena nakon 1603. kada je izrađena i skica. Za pretpostaviti je da je skica trebala poslužiti za dopunu karte, pa bi za očekivati bilo da naselja kao i ostali sadržaj prikazani na skici budu prikazani i na karti. Međutim, nije tako, a to se može vidjeti na prikazanom kopnenom području između Rijeke i Fužina te Broda na Kupi. Razlog tomu može biti da Klobučarić nije stigao dopuniti kartu s podacima koje je prikupio prilikom izrade skice. Uočili smo da su neka naselja Kvarnerskog primorja prikazana na karti kojih nema na skici i obrnuto.

Usporedbom naselja Kvarnerskog primorja prikazanih na skici i karti (slike 3 i 4), utvrdili smo da na skici nema toponima za Trsat, Bakar, Bakarac, Kraljevicu i Novi Vinodolski. Na karti od spomenutih naselja toponim za Kraljevicu nije upisan, dok Bakarac nije prikazan ni znakom, a ostala naselja prikazana su znakom. $\mathrm{Na}$ skici nisu prikazani Crikvenica i Sibinj, dok su na karti prikazani i imenovani. Selce je označeno $i$ imenovano na skici, a na karti nije.

\subsection{Usporedba toponima Kvarnerskog primorja s Klobučarićeve karte i s karata njegovih prethodnika}

Popelka (1932) navodi da je Klobučarić na svojim kartografskim prikazima zabilježio oko 10000 geografskih imena. Klen (1974) piše da Klobučarić imena zapisuje prema lokalnom izgovoru, kod čega su mu pomogli lokalni kazivači. Prema Markoviću (2002), za Hrvatsku su od posebne važnosti prikazi područja Gorskog kotara, 


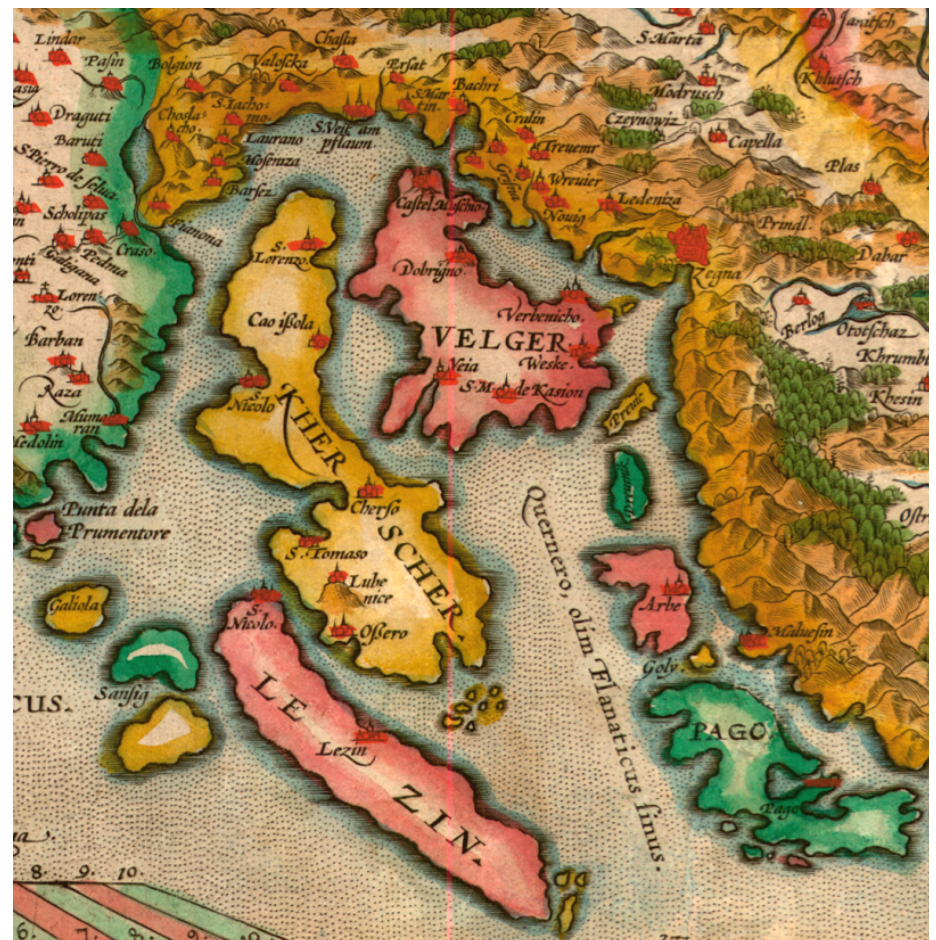

Fig. 5 Iohannes Sambucus, Illyricum, extract, 1572 (National and University Library, Zagreb, Novak Collection, call no. ZN-Z-XVI-SAM-1572c). The extract is published with the permission of the National and University Library in Zagreb and may not be reproduced.

Slika 5. Iohannes Sambucus, Illyricum, isječak, 1572. (Nacionalna i sveučilišna knjižnica, Zagreb, Zbirka Novak, sign. ZN-Z-XVI-SAM-1572C). Isječak karte objavljuju se uz dozvolu Nacionalne i sveučilišne knjižnice u Zagrebu te se ne smije reproducirati.
Klobučarić made the map between 1590 and 1600 for the purpose of defence against the Turks, and it was supplemented after 1603 when the sketch was made. It can be assumed that the sketch was made in order to update the map, so we would expect the settlements and other contents on the sketch to appear on the map. However, this is not the case, as can be seen in the mainland area between Rijeka and Fužine and Brod na Kupi. Perhaps Klobučarić did not manage to supplement the map with information gathered while compiling the sketch. We noticed that some of the Kvarner Littoral settlements on the map are not found on the sketch, and vice versa.

A comparison of the Kvarner Littoral settlements shown on both the sketch and map (Figs. 3 and 4) established that there are no toponyms on the sketch for Trsat, Bakar, Bakarac, Kraljevica and Novi Vinodolski. On the map, the toponym for Kraljevica does not appear, and Bakarac is not even shown with a sign, while the other settlements have signs. On the sketch, Crikvenica and Sibinj do not appear, while they are shown and marked on the map. Selce is marked and named on the sketch, but not on the map.

\subsection{Comparison of Kvarner Littoral toponyms on Klobučarić's map and those of his predecessors}

Popelka (1932) says that Klobučarić wrote about 10,000 geographical names on his cartographic depictions. Klen (1974) says that Klobučarić wrote the names according to local pronunciation, helped by local people. According to Marković (2002), the depictions of Gorski Kotar, Vinodol, Brinje, Modruš and Gacka with the border area along the River Una were of particular importance. However, up to now, no-one has conducted a comparison of the toponyms on Klobučarić's depictions and those on maps made by his predecessors. Therefore, we present in this paper a comparison of toponyms from part of Klobučarić's map, the Kvarner Littoral, with those on earlier maps.

In our comparison we used the 1572 Illyricum map by Iohannes Sambucus (Fig 5.) and the 1573 map by Augustin Hirschvogel, Schlavoniae, Croatiae, Carniae, Istriae, Bosniae finitimarumque regionum nova description (Fig. 6). We also used a 1566 map by Fernando Bertelli, the Venetian cartographer, entitled Novo dissegno della Dalmatia et Crovatia. ${ }^{7}$

Peloza (1975) says that Klobučarić used Italian names for the cities in Croatia, and German names for most of the cities in Slovenia, and for the villages he wrote the Croatian and Slovene names. From the toponyms in Table 2 we can see that Bertelli and Klobučarić gave Rijeka and Senj Italian names, while Sambucus and Hirschvogel gave them German names. Klobučarić mostly transmitted (partly adapted) names from Italian (for example Albona, Fiume, Berbir/Bribir, Cernouiza/ Czricueniza, Segna/Segnia), and less from German. We can also see differences in the spelling of

\footnotetext{
${ }^{7}$ An example of Bertelli's map is kept at the National and University Library in Zagreb, call no. S-JZ-XVI-28. It can be viewed at http://db.nsk.hr/HeritageDetails.aspx?id=929 (26.11. 2018).
} 


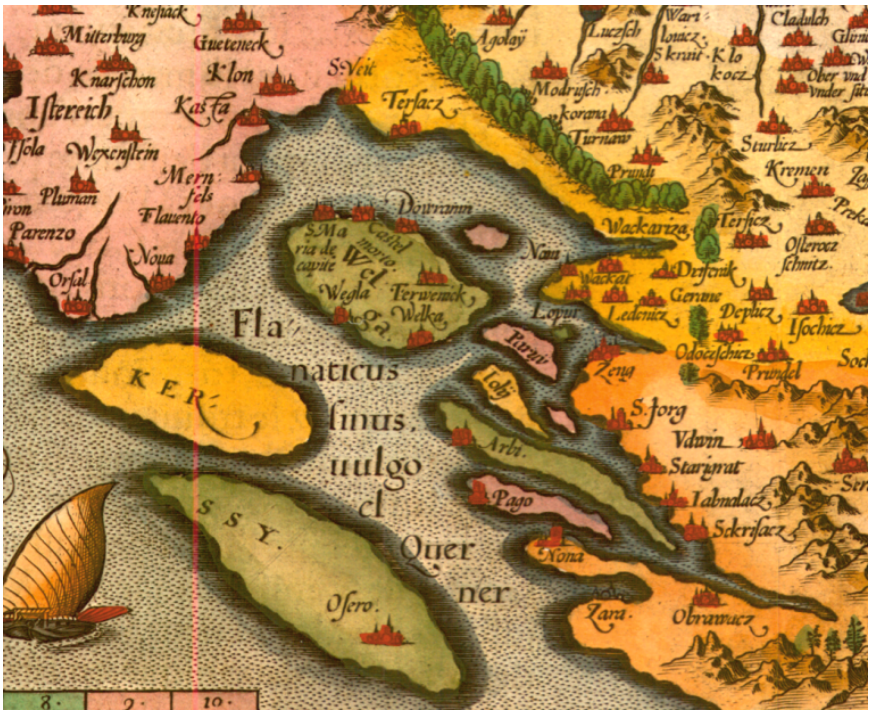

Fig. 6 Augustin Hirschvogel, Schlavoniae, Croatiae, Carniae, Istriae, Bosniae finitimarumque regionum nova descriptio, extract, 1573 (National and University Library, Zagreb, Novak Collection, call no.

ZN-Z-XVI-HIR-1573d).

The extract is published with the permission of the National and University Library in Zagreb and may not be reproduced.

Slika 6. Augustin Hirschvogel, Schlavoniae, Croatiae, Carniae, Istriae, Bosniae finitimarumque regionum nova descriptio, isječak, 1573. (Nacionalna i sveučilišna knjižnica, Zagreb, Zbirka Novak, sign. ZN-Z-XVI-HIR-1573d).

Isječak karte objavljuju se uz dozvolu Nacionalne i sveučilišne knjižnice u Zagrebu te se ne smije reproducirati.

Vinodola, Brinja, Modruša i Gacke te pograničnog područja uz rijeku Unu. Međutim, do sada nije provedena usporedba toponima s Klobučarićevih prikaza i s karata njegovih prethodnika. Stoga u radu donosimo usporedbu toponima dijela Klobučarićeve karte i to područja Kvarnerskog primorja s toponimima toga područja na kartama koje su izrađene ranije.

Za usporedbu toponima prikazanih na dijelu Klobučarićeve karte $s$ toponimima na kartama ranijih kartografa, upotrijebili smo kartu Illyricum iz 1572. Iohannesa Sambucusa (slika 5) i kartu Schlavoniae, Croatiae, Carniae, Istriae, Bosniae finitimarumque regionum nova descriptio iz 1573. Augustina Hirschvogela (slika 6). Osim spomenutih karata, upotrijebili smo i kartu mletačkog kartografa Fernanda Bertellija Novo dissegno della Dalmatia et Crovatia iz $1566 .^{7}$

Peloza (1975) navodi da je Klobučarić za gradove u Hrvatskoj upotrebljavao talijanska imena, a za većinu gradova u Sloveniji njemačka te da je za sela unosio pučka hrvatska i slovenska imena. Na osnovi toponima danih u tablici 2 može se uočiti da su Bertelli i Klobučarić Rijeku i Senj imenovali na talijanskom jeziku, dok su Sambucus i Hirschvogel na njemačkom jeziku. Klobučarić je uglavnom prenosio (dijelom i prilagođavao) imena iz talijanskog jezika (npr. Albona, Fiume, Berbir/Bribir, Cernouiza/Czricueniza, Segna/Segnia), manje i njemačkog. Također se može vidjeti razlika u pisanju pojedinih toponima za isto naselje na kartama na kojima je napisan toponim, npr. za Crikvenicu. Na Klobučarićevoj karti prikazana su i manja naselja (Žrnovnica, Sibinj, Sv. Jelena, Prizna i Cesarice) kojih nema na kartama njegovih prethodnika. Osim toga,

\footnotetext{
${ }_{7}$ Primjerak Bertellijeve karte čuva se u Nacionalnoj i sveučilišnoj knjižnici u Zagrebu pod sign. S-JZ-XVI-28. Karta se može pregledavati na internetskoj adresi

http://db.nsk.hr/HeritageDetails.aspx?id=929 (26.11. 2018.).
}

duž obala otoka Cresa, Lošinja i Raba nalaze se toponimi za uvale, dok na kartama ranijih kartografa uopće nema imena uvala. Neke od tih toponima nismo uspjeli identificirati, a za neke nam nisu poznata njihova suvremena geografska imena za koja smo u tablici napisali upitnik. Zanimljivo je da Klobučarić nije prikazao naselja na otoku Krku niti je imenovao njegove uvale. Međutim, Sambucus i Hirschvogel prikazuju i imenuju nekoliko naselja na otoku Krku, a Sambucus i na otoku Cresu.

\section{Zaključak}

Klobučarićeva kartografska ostavština je bogata, ali nedovoljno istražena. Obuhvaća kartografske prikaze većeg dijela Štajerske, Kranjske, Gorice, Hrvatske, austrijske Istre i manji dio Koruške. Posebna vrijednost Klobučarićeva topografskog i kartografskog rada je $u$ tome što je kartografske prikaze izrađivao na temelju prikupljenih podataka i vlastitih mjerenja. Njegova je ostavština od velike važnosti za Hrvatsku jer sadrži dvadesetak kartografskih prikaza na kojima su predočena hrvatska područja bogata toponimima. Usporedbom zastupljenosti naselja Kvarnerskog primorja prikazanih na Klobučarićevoj skici i karti utvrdili smo da su neka naselja označena i imenovana na skici kojih nema na karti i obrnuto. Zaključili smo da Klobučarićeva karta sadrži toponime kojih nema na kartama njegovih prethodnika. Velika važnost njegovih prikaza je u tome što je Klobučarić njihovom izradom doprinio boljem poznavanju zapadne Hrvatske i pisanju toponima prema mjesnim izgovorima.

S obzirom na to da je dio područja prikazanoga na Klobučarićevoj karti, na prijelazu iz 16. u 17. stoljeće bio pod turskom okupacijom, pretpostavljamo da te krajeve Klobučarić nije prikazao prema osobnim podacima već na osnovi podataka preuzetih s već postojećih karata. 
certain toponyms on the maps which give names, for example, Crikvenica. Klobučarić's map shows smaller settlements (Žrnovica, Sibinj, Sveta Jelena, Prizna and Cesarice) which do not appear on maps by his predecessors. In addition, there are toponyms for the bays along the coasts of Cres, Lošinj and Rab, while the earlier maps do not name these bays at all. We were unable to identify some toponyms, and we were unsure of the contemporary geographic names of others, so we have put question marks in the table. It is interesting that Klobučarić did not show the settlements on the island of Krk and did not name its bays. Yet Sambucus and Hirschvogel show and name several settlements on Krk, and Sambucus gives some on the island of Cres.

\section{Conclusion}

Klobučarić's cartographic legacy is substantial, but has been inadequately researched to date. It includes cartographic depictions of most of Styria, Carniola, Gorizia,
Croatia, Austrian Istria and some of Carynthia. It is particularly valuable because his cartographic depictions were produced as a result of gathering data and taking his own measurements. His legacy is very important to Croatia, as it includes around twenty cartographic depictions showing Croatian areas, with many toponyms. Comparing the representation of the Kvarner Littoral settlements shown on Klobučarićs's sketch and map, we established that some settlements were marked and named on the map, but not on the sketch, and vice versa. We concluded that Klobučarićs map contained toponyms absent from the maps of his predecessors. Klobučarić made an important contribution to a better understanding of western Croatia, writing toponyms according to local pronunciation.

Since part of the area covered by Klobučarićs map was under Turkish occupation in the late 16th and early 17th centuries, it can be assumed that he did not depict it according to data he had gathered himself, but relied on data from earlier maps.

\section{References / Literatura}

Crljenko I, Šeparović A (2009) Klobučarić, Ivan (Joannes Clobucciarich Fluminensis). U: Macan T (ur.) Hrvatski biografski leksikon, sv. 7, Leksikografski zavod Miroslav Krleža, Zagreb, 394-395

Klen D (1974) Slikar i kartograf Ivan Klobučarić. Dometi, br. 4, 24-33

Klen D (1975) Ivan Klobučarić, slikar i kartograf (XVI-XVII st.). Krčki zbornik, br. 6, 75-90

Lapaine M, Kljajić I (2009) Hrvatski kartografi, biografski leksikon. Golden marketing - Tehnička knjiga, Zagreb

Laszowski E (1937) Ivan Klobučarić, hrvatski kartograf. Jutarnji list, 13. srpnja, 18

Marković M (1993) Descriptio Croatiae. Naprijed, Zagreb

Marković M (2001) Hrvatski gradovi na starim planovima i vedutama. AGM, Zagreb

Marković M (2002) Kartograf Ivan Klobučarić i Rijeka. Adamić, Naklada Benja i Povijesno društvo otoka Krka, Rijeka

Mlinarić D (1998) Hrvatski doprinos srednjoeuropskoj kartografiji 17. stoljeća. Geodetski list, br. 3, 205-214

Nepokoj D (ur.) (2010) Gradski toranj. Pomorski i povijesni muzej Hrvatskog primorja Rijeka, Rijeka

Novosel-Žic P, Richter-Novosel Ž (2005) Hrvatski kartografi 16. i 17. stoljeća / Croatian Cartographers of the 16th and 17th Centuries.

U: Novak D, Lapaine M, Mlinarić D (ur.) Pet stoljeća geografskih i pomorskih karata Hrvatske / Five Centuries of Map and Charts of Croatia, Školska knjiga, Zagreb, 86-111

Peloza M (1975) Arhitekt i kartograf Ivan Klobučarić. Jadranski zbornik, sv. 9, 287-294

Peruško T (1958a) Jedno novo ime u našoj kulturnoj historiji, Kartograf Ivan Klobučarić iz Dubašnice. Riječka revija, br. 6, 441-442

Peruško T (1958b) Kartograf Ivan Klobučarić. Geografski glasnik, br. 20, 152-153

Popelka F (1923) Ein unbekannter innerösterreichischer Kartograph um die Wende des 16. Jahrhunderts. Mitteilungen der geographischen Gesellschaft, Band 66, 101-106

Popelka F (1932) Bericht über das im steiermärkischen Landesregierungsarchiv liegende Skizzenmaterial zur Landesaufnahme Innerösterreichs von 1601 bis 1605. Anzeiger der Akademie der Wissenschaften in Wien, Philosophisch-historische Klasse, 196-203

Posch F (1974) E. Popelka. Mitteilungen des Steiermärkischen Landesarchivs, Folge 24, 29-34

Slukan Altić M (2003) Povijesna kartografija - Kartografski izvori u povijesnim znanostima. Meridijani, Samobor

Trobas K (1971) Die Restaurierungsarbeiten an den Blättern der innerösterreichischen Landesaufnahme des Johannes Clobucciarich. Mitteilungen des Steiermärkischen Landesarchivs, Folge 21, 147-149

Žic I (2003) Klobučarić i njegovo vrijeme. Sušačka revija, br. 41, 119-129

URL 1: Steiermärkisches Landesarchiv, Service, Online-Recherche (Zur Online-Recherche), Beständestruktur (Staatliche Hoheitsverwaltung, Staatliche Hoheitsverwaltung-Sonderbestände, Clobucciarich - Skizzen), https://egov.stmk.gv.at/archivinformationssystem/objekt.jsp?id=155 (26. 11. 2018.)

URL 2: Steiermärkisches Landesarchiv, Service, Newsletter-Archiv (Newsletter des Steiermärkischen Landesarchivs vom 23.12.2014), http://www.landesarchiv.steiermark.at/cms/beitrag/12164723/111652853/ (26. 11. 2018.)

URL 3: Steiermärkisches Landesarchiv, Service, Online-Recherche (Zur Online-Recherche), Beständestruktur (Staatliche Hoheitsverwaltung, Staatliche Hoheitsverwaltung-Sonderbestände, Clobucciarich - Skizzen (Clobucciarich-001 - Clobucciarich-108b)), https://egov.stmk.gv.at/archivinformationssystem/at/jr/iis/imdas/web/objektliste/load-objektliste.jsf?objektld=155 (26. 11. 2018.) 